\title{
Removal of Capybara (Hydrochoerus hydrochaeris) population as measure to control Amblyomma tick population and reduce Brazilian Spotted Fever transmission risk in a Gated Community in Bragança Paulista (SP, Brazil) - Case Study
}

\author{
Remoção de capivaras (Hydrochoerus hydrochaeris) como ação para \\ controle da população de carrapatos Amblyomma e redução do risco \\ de transmissão da Febre Maculosa Brasileira em um Condomínio \\ Residencial em Bragança Paulista (SP, Brasil) - Estudo de Caso
}

\author{
Adriana Akemi KUNIY ${ }^{1 *}$; Ciro Antônio DIAS ${ }^{2}$; Celso de SOUZA ${ }^{3}$; Francisco Conrado de Mendonça UCHOA \\ Thaís Guimarães LUIZ ${ }^{4}$; Monicque Silva PEREIRA ${ }^{4}$; Débora Bonilha VASQUEZ²; Marcello Schiavo NARDI'; \\ Priscila Machion LEONIS ${ }^{1}$; Vitor ARRUDA ${ }^{1}$; Sóstenes PELEGRINII ${ }^{1}$; Harley Sebastião da SILVA ${ }^{1}$; \\ Leandro Perez GODOY'; Thiago Macek Gonçalves ZAHN ${ }^{5,6}$ \\ ${ }^{1}$ JGP Consultoria e Participações Ltda, Departamento de Fauna Terrestre, São Paulo - SP, Brazil \\ ${ }^{2}$ Residencial Quinta da Baroneza, Bragança Paulista - SP, Brazil \\ ${ }^{3}$ Secretaria de Estado da Saúde - Superintendência de Controle de Endemias (SUCEN), São Paulo - SP, Brazil \\ ${ }^{4}$ Secretaria do Meio Ambiente do Estado de São Paulo - Coordenadoria de Biodiversidade e \\ Recursos Naturais, Departamento de Fauna Silvestre, São Paulo - SP, Brazil \\ Universidade de São Paulo, Instituto de Biociências, Departamento de Genética e Biologia Evolutiva, São Paulo - SP, Brazil \\ ${ }^{6}$ Universidade de São Paulo, Faculdade de Filosofia, Letras e Ciências Humanas, Departamento de Linguística, São Paulo - SP, Brazil
}

\begin{abstract}
This study reports the factors which led a gated community located in Bragança Paulista (SP, Brazil), a non-endemic area for Brazilian Spotted Fever (BSF), to be classified as a Risk Area for transmission of this disease, showing that an increasing resident population of capybaras (Hydrochoerus hydrochaeris) in the area was likely responsible for a proliferation of Amblyomma sculptum ticks and acted as an amplifying host for Rickettsia rickettsii, the main etiologic agent of BSF. We report management actions proposed to control the local tick burden and reduce BSF risk, including measures to control parasitic and free-living tick populations and exclusion of the resident capybara population. Analyses of tick population data and $R$. rickettsii serology tests indicate that these measures were effective, greatly reducing the environmental burden of Amblyomma sculptum ticks and reducing the BSF transmission risk at the area. Keywords: Rickettsia rickettsii. Ticks. Amblyomma sculptum. Hydrochoerus hydrochaeris. Public health risk.
\end{abstract}

\section{Resumo}

Este estudo relata os fatores que levaram um Residencial localizado em Bragança Paulista (SP, Brasil), área não-endêmica para Febre Maculosa Brasileira (FMB), a ser classificado como Área de Risco para a doença, mostrando que uma crescente população residente de capivaras (Hydrochoerus hydrochaeris) na área era a provável responsável por uma proliferação de carrapatos Amblyomma sculptum e estava atuando como hospedeiro amplificador da bactéria Rickettsia rickettsii, principal agente etiológico da FMB. Relatamos as ações de manejo ambiental propostas para controlar a quantidade de carrapatos no local e reduzir o risco de transmissão da doença, incluindo medidas para o controle de populações de carrapatos parasíticas e no ambiente e a eliminação da população residente de capivaras. Análises de dados populacionais de carrapatos e testes serológicos para $R$. rickettsii indicaram que as medidas tomadas foram efetivas, causando grande redução da população de carrapatos no ambiente e reduzindo o risco de transmissão de FMB na área.

Palavras-chave: Rickettsia rickettsii. Carrapatos. Amblyomma sculptum. Hydrochoerus hydrochaeris. Risco de saúde pública. 
Correspondence to:

Adriana Akemi Kuniy

JGP Consultoria e Participações Ltda, Departamento de Fauna

Terrestre

Rua Américo Brasiliense, 615 - Chácara Santo Antonio

CEP: 04715-003, São Paulo, SP, Brazil

e-mail: aakuniy@gmail.com

Received: 06/02/2018

Approved: 09/10/2018

\section{Introduction}

Brazilian Spotted Fever (BSF) is a tick-borne zoonotic disease caused by the gram-negative bacterium Rickettsia rickettsii, and has great Public Health importance in Brazil due to its high fatality rates in humans (GALVÃO et al., 2003; LIMA et al., 2003; KATZ et al., 2009; PINTER et al., 2011). Lethal cases of BSF in the state of São Paulo have been reported since at least 1932 (PIZA, 1932), and the disease has reemerged in various areas of the state during the 1980s and 1990s (LIMA et al., 2003; ANGERAMI et al., 2006; KATZ et al., 2009). Notification of new cases of the disease was made compulsory in Campinas, in the state of São Paulo, in 1996 (LIMA et al., 2003), and shortly afterwards throughout the country in 2001 (BRASIL, 2001). São Paulo was the likely origin of most confirmed cases of BSF in Brazil between 2007 and 2012 (44.14\% of all confirmed cases), and had the highest fatality rate (41.35\%) and the second highest person-time incidence rate (behind Santa Catarina) during this period (BARROS E SILVA et al., 2014). A large proportion of BSF cases in São Paulo is concentrated in specific, endemic areas of the state (KATZ et al., 2009; RIBEIRO et al., 2013), although the disease has spread to previously unaffected municipalities between 2003 and 2008 (KATZ et al., 2009).

The main vector of BSF is Amblyomma sculptum (KATZ et al., 2009), a three-host tick whose adult stage uses tapirs (Tapirus terrestris), capybaras (Hydrochoerus hydrochaeris) and possibly peccaries (Tayassu pecari, Pecari tajacu) as its primary wild hosts (ARAGÃO, 1936; LABRUNA et al., 2002b; LABRUNA et al., 2005; PEREZ et al., 2008; NAVA et al., 2014; MARTINS, 2014), but may also occur on horses (OLIVEIRA, 1998; LABRUNA et al., 2002a) and cattle (SERRA-FREIRE, 1982). The tick's immature stages have lower host specificity, occurring on some birds and a variety of medium- and large-sized mammals, including humans (PEREIRA; LABRUNA, 1998; LABRUNA et al., 2001; LABRUNA et al., 2002b; GUGLIELMONE et al., 2003; LABRUNA et al., 2005; PEREZ et al., 2008,).
Besides acting as a primary host for the adult stage of A. sculptum, capybaras may be infected by its immature stages (PEREZ et al., 2008), are susceptible to Rickettsia rickettsii infection, maintain viable rickettsemia for 1-2 weeks, and may infect immature A. sculptum ticks which feed on them, being therefore a viable amplifying host for $R$. rickettsii among tick populations (SOUZA et al., 2009; LABRUNA, 2013). As recently argued by some authors, the rising capybara population in São Paulo may be causally related to the re-emergence of BSF in the state (LABRUNA, 2009; DEL FIOL et al., 2010; LABRUNA, 2013), and therefore large capybara populations may represent an increased transmission risk for the disease (SANGIONI et al., 2005). In many parts of inland São Paulo, large capybara populations may gather in areas with large availability of food and shelter, such as suburban real estate development areas and gated communities. Although capybaras are not the only species associated with higher risk of BSF transmission to humans, the potential for increased risk with rising numbers of this mammal means that transmission risk should be appropriately assessed and managed in areas with large and/or growing capybara populations.

Here we report on the factors which led a gated community in a non-endemic area of the state of São Paulo to be identified as a BSF transmission risk area, describe the measures taken to control Amblyomma tick populations and lower the local transmission risk, including complete fencing of the gated community and removal of the local capybara population, and analyze the results of approximately 2 years of Amblyomma tick monitoring performed to assess the effectiveness of the management measures taken.

\section{Materials and Methods}

\section{Study Area and Background}

The study area is a gated community located in Bragança Paulista - SP (23 K 325.945 L / 7.457.378 S UTM), a municipality previously considered non-endemic for BSF, with no known incidence and low priority for the disease between 1998 and 2010 (RIBEIRO et al., 2013), but geographically close to the endemic Campinas region. Tick population surveys performed on horses and capybaras and using dry-ice tick traps and tick dragging have shown continued presence of the tick Amblyomma sculptum in the area since 2004 (see Figure S.1 for results 
of dry-ice traps and tick dragging between May 2004 and May 2005). Mammal monitoring activities in the area at the time of these first surveys have shown that areas with greatest capybara population densities were also the most tick-infested. This has led to the installation of $1.5 \mathrm{~m}$ high fences surrounding most of the gated community in 2007 (see Figure 1 for a detail of part of the perimeter) as a measure to exclude capybaras from areas used by horses, and to the application of acaricides (pyrethroids) on horses kept at the community's stud farm and in areas frequented by these animals. The gated community's inhabitants also decided to use horses as sentinel animals for surveillance of Rickettsia rickettsii circulation in the area. These initial measures apparently controlled tick infestation on horses and BSF risk at the time; serological tests performed between 2010 and 2012 identified rickettsial exposure in only one horse, which had been brought from a different stud farm shortly before the test.

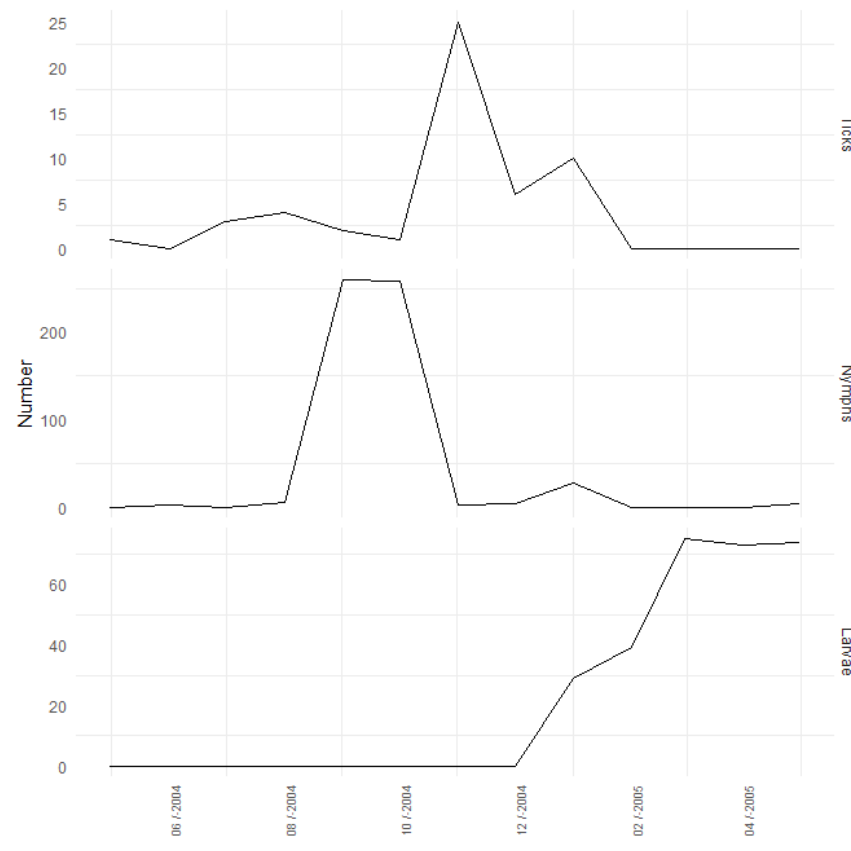

Figure S.1. - Number of adult Amblyomma sculptum and nymphs and larvae of Amblyomma sculptum or Amblyomma sp. registered in previous tick surveys with dry-ice traps and tick dragging, performed in the gated community between May 2004 and May 2005

The surveys also identified 3 adult and 6 nymph Amblyomma dubitatum (not shown).

In 2012, mammal monitoring activities in the gated community identified an increase in the local capybara population and a high number of young and juvenile specimens. In view of possible causal relations between large capybara populations and BSF risk (LABRUNA, 2009; DEL FIOL et al., 2010; SANGIONI et al., 2005; LABRUNA,
2013; SOUZA et al., 2015), this population surge led to concerns about public health risks in the area, and the decision was taken to carry out analyses to classify the local risk of BSF transmission.

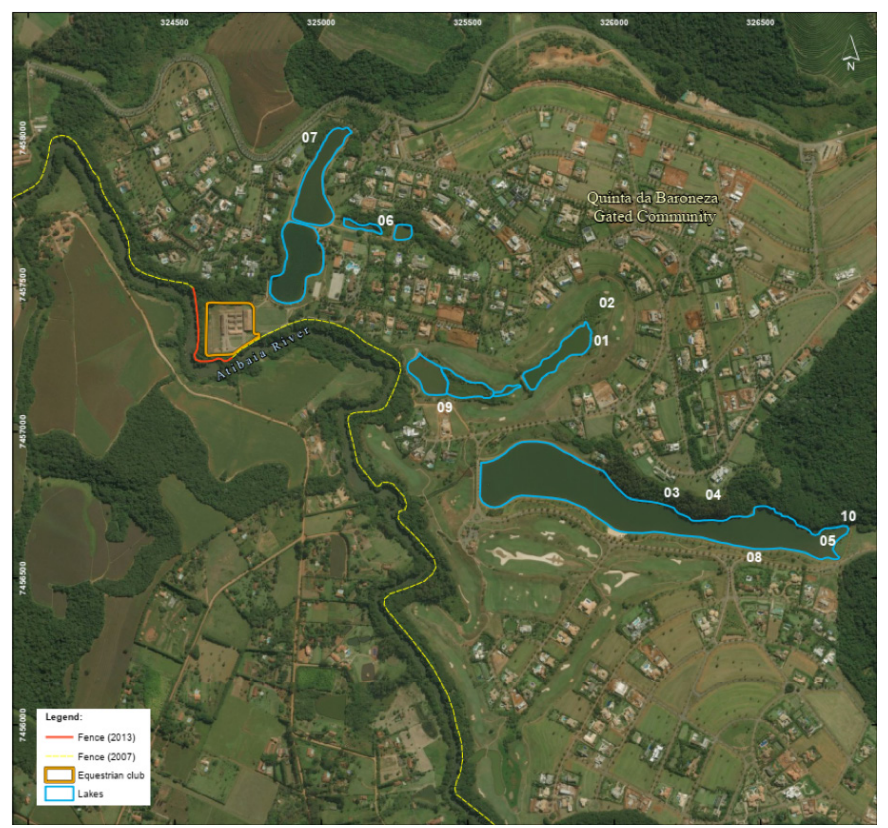

Figure 1 - Map of the study area showing parts of the perimeter, which was fenced in 2007 and 2013, the location of the gated community's equestrian club, lakes used by capybaras, and the sampling points used for tick population monitoring surveys (numbered 1 to 10 , in white)

\section{Preliminary Analyses to Classify BSF Transmission Risk}

Based on an agreement signed by the gated community, the São Paulo Environmental State Secretariat - SMA, and the São Paulo State Superintendence for Control of Endemic Diseases - SUCEN (SMA/CBRN/DeFau n. 002/2012), the following analyses were performed to classify the BSF transmission risk at the gated community: 1. Capybara population survey in accordance with observation and counting methods recommended by IBAMA (2006); 2. Preliminary tick survey performed by SUCEN to inspect the presence of Amblyomma ticks, in accordance with São Paulo (2004) and Pinter (2013); 3. Serological test for $R$. rickettsi on horses kept in the gated community's stud farm; and 4. Capybara captures for blood sampling and $R$. rickettsi serological tests.

Capybara population surveys during this preliminary stage were performed in October 2012, and preliminary tick surveys were carried out in early 2013.

Capybara captures for serological tests were supported by the Authorization for In Situ Management n. 56/2013 (SMA Process n. 11.584/2012), which approved the 
following methods: use of corn or sugarcane as bait to attract the animals; capture in corrals; chemical restraint (intramuscular doses of ketamine and xylazine applied with blowpipes) for collection of biological material and later release of the animals. Blood samples were collected by venipuncture of capybaras' cephalic vein, using an vacuum tube system. Capybara captures and serological tests in this initial stage took place between June and September 2013. Serological tests on the horses kept in the gated community's stud farm were performed in September 2013.

Serological tests on horse and capybara samples followed the methods described in Souza et al. (2008) and Sangioni et al. (2005). After collection, blood samples were kept at room temperature to promote clot retraction, then centrifuged at $3000 \mathrm{rpm}$ for 10 minutes to obtain blood serum. Seropositivity for $R$. rickettsi was detected using an Indirect Immunofluorescence Assay (IFA), in which a serum sample was diluted in PBS (phosphorus buffer solution) and placed on a slide containing $R$. rickettsii antigen, and positive and negative control sera. IFAs employed serum samples at different dilutions (1/64 to $1 / 2048)$. The tests used anti-capybara conjugate produced by CCZ/SP following the procedure described in Souza et al. (2008), as well as SIGMA-ALDRICH commercial anti-horse conjugate. Serological tests at this stage were performed on 58 capybaras and 66 horses.

Concomitantly with the preliminary analyses above, SUCEN recommended additional environmental management measures (see LABRUNA et al., 2013) to be followed by the gated community in order to control the local tick population and reduce the risks of $R$. rickettsii transmission to residents and staff: 1 . Grass mowing in overgrown areas; 2. Staff use of Personal Protective Equipment (PPE) when crossing possibly tick-infested areas; 3 . Instructions to staff and residents to perform body inspections after walking on possibly tick-infested areas; 4. Installation of signs informing about tick-infested areas.

\section{Control of Tick Population and BSF Risk}

As a report by SUCEN based on preliminary analyses (Of. Lab. Mogi Guaçu - n. 07/13 - ET) classified the gated community as a risk area for BSF transmission (see results), the competent environmental and health authorities (SMA and SUCEN) indicated management measures to control the tick population and transmission risk, including: 1. Continuation of the aforementioned environmental management measures and educational and awareness raising activities directed to staff and residents to control free-living tick populations, reduce the risk of human contact with ticks and shorten the time with ticks attached if contact occurs; 2. Continuous application of acaricides in areas used by horses in order to control the parasitic tick population; 3 . Removal of the capybara population in the gated community in order to exclude the most important primary host for A. sculptum in the area; and 4. Fencing of the only section of the gated community's perimeter still open, between the riparian forest along the Atibaia River and the gated community's Permanent Preservation Area (APP) (CETESB Process n. 69423/00), with 3-meter-high wire fences (see Figure 1), before the start of capybara removal activities. This last measure was important to avoid recolonization of the area by capybaras, since otherwise the elimination of a capybara population might lead to its replacement by other individuals living nearby, possibly increasing the local population (and consequently the BSF risk) in the medium term (LABRUNA, 2013).

The decision to remove the local capybara population is supported by Brazilian Federal Law n. 9605/1998 (Environmental Crimes Law), Article 37, item 4, according to which "Killing an animal is not a crime when this is performed due to the animal in question being considered harmful, according to a characterization by the competent authority" (BRASIL, 1998), and by Brazilian Federal Law $n$. 5197/1967, Article 3, item 2, which indicates that "catching eggs, larvae and young destined to the establishments mentioned above, and destroying wild animals considered harmful to agriculture or to public health shall be allowed under a license issued by the competent authority" (BRASIL, 1967). A new survey was conducted in October 2013, before the start of activities to capture and remove capybaras, in order to update existing information about the local population.

The authorization to capture and sacrifice capybaras was supported by Authorization for In Situ Management n. 123/2013 (SMA Process n. 11.584/2012). The euthanasia protocol used followed the guidelines in Resolution n. 1000/2012 of the Brazilian Federal Council of Veterinary Medicine (CFMV), and carcasses were sprayed with acaricides, packed in hospital waste bags and kept in a refrigerated container inside the gated community until their final disposal by incineration. The procedures for disposal of the carcasses were supported by CETESB Process n. 60/00547/13 and the Certification of Approval for Hazardous Waste Destination (Certificado de Movimentação de Resíduos de Interesse Ambiental - CADRI) n. 60001152. 
To evaluate the success of actions to remove the local capybara population, the competent environmental authority (SMA) requested additional non-invasive capybara population surveys, performed in three nonconsecutive days every two months. These surveys were performed at least once per month between January and August 2014, always after the euthanasia procedures for the month in question were completed, allowing estimation of the remaining capybara population. Data on the remaining capybaras or signs of presence of the species observed in the surveys were used along with the number of animals euthanized during each month to obtain an estimate of the capybara population present inside the gated community at the start of each month between October 2013 and August 2014. The capybara population was considered to remain the same after August 2014, as mammal monitoring campaigns in the gated community did not identify any signs of an increased local capybara population (results not shown as these campaigns are not the focus of this study).

The effectiveness of the management measures above in reducing tick populations and the local BSF transmission risk was assessed through Amblyomma tick population monitoring and one additional serological test on horses kept at the gated community. Tick population monitoring was carried out by SUCEN's team for almost two years after the start of the activities for capybara removal, between February 2014 and November 2015, using tick dragging and dry-ice traps at 10 sampling points in the margins of lakes inside the gated community or in nearby areas (Figure 1). The sampling effort used was the same in all sampling points. Although Oliveira (1998) suggested that the marked symmetry of infestations by the three parasitic stages of A. sculptum would allow adequate population estimates by counting only one stage, the tick surveys performed by SUCEN obtained information on all three free-living stages of Amblyomma ticks in the area. While all adult ticks collected during these surveys were identified at the species level, nymphs and larvae were identified only as Amblyomma sp. As the focus of our analysis was the main vector of Brazilian Spotted Fever, Amblyomma sculptum, and 96.9\% of all adult ticks belonged to this species, we considered all nymphs and larvae as A. sculptum for downstream analyses.

The additional serological test on horses at the gated community's stud farm was performed in December 2014, approximately eight months after the end of capybara removal activities. This test was performed on 60 horses, 38 of which had also been tested in October 2013.

\section{Data Analysis and Statistics for Tick Population Data and Serological Tests}

Tick population data and the results of horse serological tests were analyzed using different methods to assess the effects of the management actions taken on tick populations and the BSF risk in the area. All statistical analyses were run on the $\mathrm{R}$ programming environment, version 3.5.0 (R CORE TEAM, 2013).

\section{Tick Population Data}

As the tick population surveys obtained data for 17 months between February 2014 and November 2015, we used linear interpolation (function na.approx in $\mathrm{R}$ package 'zoo' - ZEILEIS; GROTHENDIECK, 2005) to estimate the population of the three free-living stages of $A$. sculptum in the five months with missing data, in order to obtain complete time series for this period. This was done separately for each sampling point and for the total population in the gated community (i.e., sum of all sampling points). Observed and estimated numbers of $A$. sculptum adults, nymphs and ticks for the gated community as a whole are shown in Figure S.2. Downstream analyses used the complete time series for the total population of each stage (adults, nymphs and larvae) in the gated community as a whole.

In order to identify particularities of the temporal dynamics of each A. sculptum stage and to assess whether the management measures taken had contributed to a reduction of the local tick population, we performed regressions of the population of each stage on time (months), modelling the error term with a non-seasonal ARMA (Autoregressive-moving-average) model, fit automatically using a stepwise algorithm and the secondorder Akaike Information Criterion (AICc) for model selection ( $\mathrm{R}$ function auto.arima, package 'forecast' HYNDMAN; KHANDAKAR, 2008). The significance of estimated parameters was assessed using $\mathrm{R}$ function coeftest (package lmtest - ZEILEIS; HOTHORN, 2002). This was initially performed for the period between February 2014 and November 2015. After extending the time series to cover the period between January 2014 and December 2015 using different methods (see below), we reran these regressions to assess the robustness of the results. As the general interpretation is the same in most cases (see Table S.1), we focused on the original results using data between February 2014 and November 2015, mentioning relevant differences in interpretation where appropriate. 


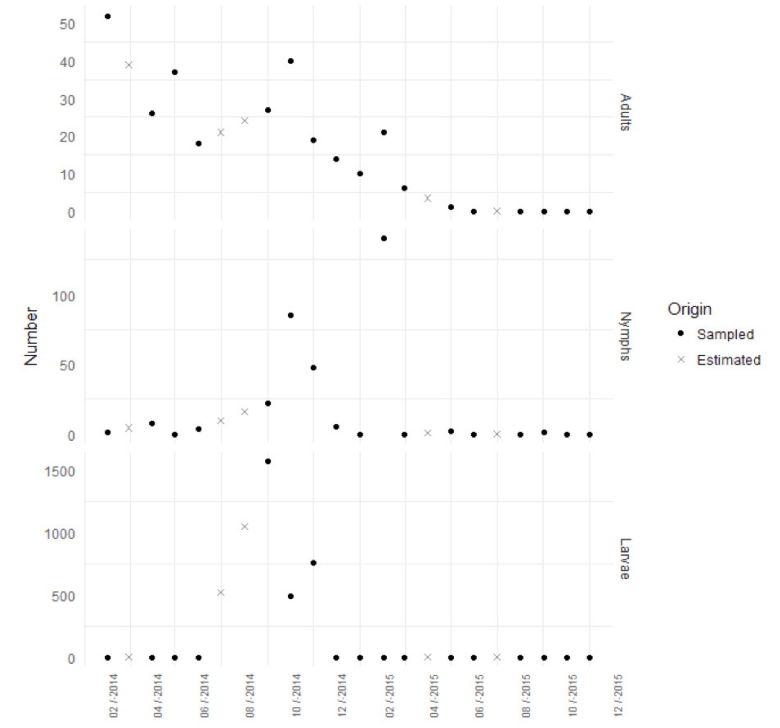

Figure S.2 - Observed number of A. sculptum adults, nymphs and ticks considering sum of results for the gated community as a whole, and values estimated for months with missing data (using linear interpolation)

Table S.1. - Results of regressions with errors following an automatically fit ARMA model for Adults, Nymphs and Larvae of $A$. sculptum using data from February 2014 to November 2014 (short) or extending time series to December 2015 (repeating the value for November 2015) and January 2014 (using the maximum, minimum or mean values of the time series, or repeating the closest value - February 2014)

\begin{tabular}{|c|c|c|c|c|c|c|c|c|c|c|}
\hline & & Intercept & sd & p-value & Time & sd & p - value & AR & sd & $p$-value \\
\hline & short & 41.195 & 3.113 & $<0.001$ & -2.165 & 0.237 & $<0.001$ & - & & \\
\hline & closest & 44.444 & 3.064 & $<0.001$ & -2.187 & 0.214 & $<0.001$ & - & & \\
\hline \multirow[t]{5}{*}{ Adults } & $\max$ & 44.444 & 3.064 & $<0.001$ & -2.187 & 0.214 & $<0.001$ & - & & \\
\hline & $\min$ & 35.777 & 4.331 & $<0.001$ & -1.667 & 0.303 & $<0.001$ & - & & \\
\hline & mean & 38.493 & 3.492 & $<0.001$ & -1.830 & 0.244 & $<0.001$ & - & & \\
\hline & short & - & & & 0.946 & 0.566 & 0.095 & - & & \\
\hline & closest & - & & & 0.804 & 0.479 & 0.093 & - & & \\
\hline \multirow[t]{5}{*}{ Nymphs } & $\max$ & 42.239 & 2.579 & 0.010 & -1.754 & 1.146 & 0.126 & - & & \\
\hline & $\min$ & - & & & 0.803 & 0.479 & 0.093 & - & & \\
\hline & mean & - & & & 0.807 & 0.481 & 0.093 & - & & \\
\hline & short & - & & & 7.131 & 13.830 & 0.606 & 0.670 & 0.146 & 0.000 \\
\hline & closest & - & & & 6.323 & 11.835 & 0.593 & 0.672 & 0.140 & 0.000 \\
\hline \multirow[t]{3}{*}{ Larvae } & $\max$ & 730.610 & 294.066 & 0.013 & -35.936 & 19.958 & 0.072 & 0.443 & 0.204 & 0.030 \\
\hline & $\min$ & - & & & 6.323 & 11.835 & 0.593 & 0.672 & 0.140 & 0.000 \\
\hline & mean & - & & & 6.227 & 11.929 & 0.602 & 0.672 & 0.142 & 0.000 \\
\hline
\end{tabular}

Significant parameters are indicated in bold $(\mathrm{p}<0.001)$ or italic $(p<0.05)$.

Time $=$ Regression on time $($ trend $) ; \mathrm{AR}=$ Autoregression parameter; $s \mathrm{~d}=$ Standard deviation .

To analyze the expected seasonal behavior of the population of each A. sculptum stage, and as an additional way to identify possible population trends, we decomposed the time series for each tick stage into seasonal and trend components using an additive model ( $\mathrm{R}$ function decompose). As this process needs a time series with at least two full years, we extended the time series for each $A$. sculptum stage to cover January 2014 and December 2015. In order to assess the robustness of the patterns observed, we used a variety of methods to obtain values for these months. For December 2015, we initially used either the closest value (November 2015) or the maximum value of the last 6 months (June to November 2015); as both methods produced virtually identical results, we kept the closest value for all analyses. For 2014, we used four methods: using the closest value (February 2014); the maximum value of the whole time series; the minimum value of the whole time series; or the mean of the time series. The resulting seasonal and trend components with these methods were also very similar in most cases (see Figure S.3), so we focus below only on results using the closest values for both January 2014 and December 2015. 


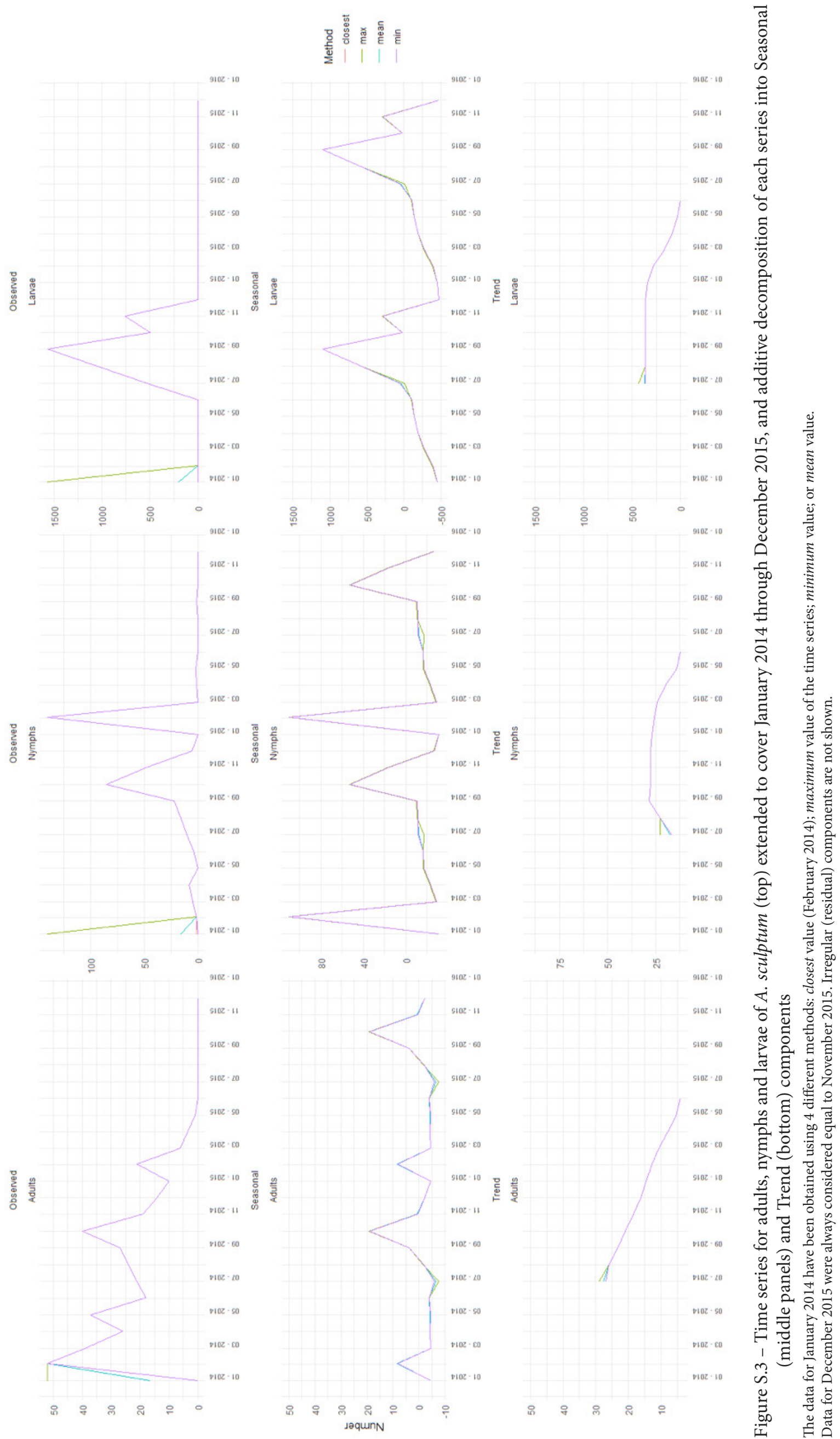

Braz. J. Vet. Res. Anim. Sci., São Paulo, v. 55, n. 4, p. 1-21, e143159, 2018 
In order to assess if removal of the local capybara population may be causally related to tick population changes and evaluate the time between removal of the primary host and changes in parasite population, we fit linear models regressing the adult tick population (February 2014 to November 2015) on the capybara population with lags ranging from 0 to 15 months, and used a model selection approach based on AIC (ANDERSON et al., 1998; BURNHAM; ANDERSON, 2001; BURNHAM; ANDERSON, 2002) and Akaike weights (BURNHAM; ANDERSON, 2001; BURNHAM; ANDERSON, 2002; WAGENMAKERS; FARRELL, 2004) (R function akaike. weights, package 'qpcR' - SPIESS, 2014) to select the most appropriate time lag.

\section{Serological Tests}

To assess whether the results of serological tests on horses performed in December 2014 indicated a significant reduction in $R$. rickettsii infection in the sentinel population in comparison to the previous test in October 2013, we used a non-parametric WilcoxonMann-Whitney test (HOLLANDER; WOLFE, 1999) with the null distribution calculated exactly ( $R$ function wilcox_test, package 'coin' - HOTHORN et al., 2008), treating reactivity at increasing titers as an ordinal variable. We used $r$ as a measure of effect size (MANGIAFICO, 2016; implemented using function wilcoxon $R$ in the R package 'rcompanion' MANGIAFICO, 2018). Although the assumption of independence of samples is violated here (as some horses were tested in both occasions), this approach makes it possible to use the whole sample to assess whether titers were generally lower in December 2014 than they were before the start of management actions.

Using only the 38 horses tested on both occasions, we also performed a non-parametric Wilcoxon signedrank test (HOLLANDER; WOLFE, 1999), with the null distribution calculated exactly, using the method proposed by Pratt (1959) for handling differences of zero. Although this test relies on lower sample size, it is more appropriate for paired data, being used here to specifically assess whether the titers of horses tested on both occasions dropped between October 2013 and December 2014. We also used $r$ as a measure of effect size for this test (function wilcoxonPairedR, package 'rcompanion' - MANGIAFICO, 2018).

\section{Results and Discussion}

\section{Preliminary Analyses to Classify the BSF Transmission Tisk in the Area}

The preliminary capybara population survey in October 2012 counted 27 individuals in lakes, golf courses and riparian forest fragments inside the gated community and $25 \mathrm{in}$ riparian forest areas alongside the Atibaia river, bordering the study area (see Figure 1, above), confirming an increase in the local population at the gated community and its immediate vicinity in comparison to previous mammal surveys at the area.

The preliminary tick surveys carried out in early 2013 identified the presence of A.sculptum and Amblyomma dubitatum in the study area (BSF Circular Letter n. 15/13 SR 05 SUCEN). The horse serological tests performed in 2013 detected $R$. rickettsii reactivity in $53.03 \%$ of the tested animals, with titers $\geq 1024$ in three animals (Table 1), indicating the circulation of spotted-fever group Rickettsia in the gated community.

Table 1 - Results of indirect immunofluorescence assays (IFA) for Rickettsia rickettsii antibodies in horses kept at the gated community's stud farm in 2013 and 2014, and antibody titers of reactive individuals

\begin{tabular}{cccccccc}
\hline & \multirow{2}{*}{ Date } & \multirow{2}{*}{$\begin{array}{c}\# \\
\text { Reactive }\end{array}$} & \multicolumn{4}{c}{$\begin{array}{c}\text { \# Reactive according to } \\
\text { antibody titer }\end{array}$} \\
\cline { 4 - 8 } & & Reactive & $\mathbf{6 4}$ & $\mathbf{1 2 8}$ & $\mathbf{5 1 2}$ & $\mathbf{1 0 2 4}$ & $\mathbf{2 0 4 8}$ \\
\hline $.9 / 2013$ & $35 / 66$. & $53.03 \%$ & 11 & 2 & 5 & 3 & - \\
$.12 / 2014$ & $21 / 60$. & $35.00 \%$ & 5 & 9 & 2 & - & - \\
\hline
\end{tabular}

The effort for blood sampling and serological tests in capybaras led to the capture and testing of 58 specimens between June 19, 2013 and September 3, 2013. All captured specimens were marked with numbered plastic earrings to avoid recaptures; the marking of one individual was lost during the specimen's release, and sex and age information for this individual were lost during the procedures. The captured specimens included a large proportion of infants (38.6\% of all individuals with sex and age information); adults (36.8\%), young adults (15.8\%) and juveniles (8.8\%). According to these data, the proportion of infants among captured individuals in the study area is higher than that found in most other studies (MOREIRA et al., 2013), although populations studied in the Brazilian Pantanal had approximately 50\% infants (SCHALLER; CRAWSHAW JUNIOR, 1981). The number of individuals captured for tests was considered another sign of a large resident population, indicating a local population density of at least $\sim 5.8 \mathrm{ind} / \mathrm{km}^{2}$. Although data from these captures is insufficient for an in-depth demographic analysis, 
the high proportion of infants might indicate rapid population growth in the area at the time of the serology tests, assuming such data is representative of the local population (i.e., not biased towards capturing infants). Most of the captured and tested individuals were female ( $73.7 \%$ of all specimens with sex and age information), corresponding to a sex ratio of 1:2.8 (males/females), which falls within expected values for capybara groups (SCHALLER; CRAWSHAW JUNIOR, 1981; HERRERA, 2013; MOREIRA et al., 2013).

Forty-two of the 58 capybaras captured and tested were seropositive for Rickettsia rickettsii, including four individuals with titers $\geq 2048$. This corresponds to a seroprevalence of $72.41 \%$ for spotted fever group rickettsiae in the local capybara population (Table 2). Seroprevalence was similar among males and females, and remarkably high in all age groups except young adults, the only group with seroprevalence $\leq$ $50 \%$. The high $R$. rickettsii seroprevalence in the local capybara population, including juveniles and infants, is particularly relevant as it indicates an ongoing epizootic episode at the time of the tests. Coupled with the preliminary acarological surveys, these results indicate that the study area was endemic for BSF at the time of the tests.

Table 2 - Results of indirect immunofluorescence assays (IFA) for anti-Rickettsia rickettsii antibodies in capybaras captured in the study area between June 19th, 2013 and September 3rd, 2013 according to specimen age and sex, and antibody titers of reactive individuals

\begin{tabular}{|c|c|c|c|c|c|c|c|c|}
\hline \multicolumn{9}{|c|}{ Female } \\
\hline \multirow{2}{*}{ Age } & \multirow{2}{*}{ \# Reactive } & \multirow{2}{*}{$\%$ Reactive } & \multicolumn{6}{|c|}{ \# Reactive according to antibody titer } \\
\hline & & & 64 & 128 & 256 & 512 & 1024 & 2048 \\
\hline Infant & $11 / 16$ & $68.75 \%$ & 1 & 1 & 8 & 1 & & \\
\hline Juvenile & $3 / 4$ & $75 \%$ & 1 & & 1 & & & 1 \\
\hline Young adult & $1 / 3$ & $33.33 \%$ & & 1 & & & & \\
\hline Adult & 15/19. & $78.95 \%$ & 3 & 9 & 2 & & & 1 \\
\hline Total & $30 / 42$ & $71.43 \%$ & 5 & 11 & 11 & 1 & & 2 \\
\hline \multicolumn{9}{|c|}{ Male } \\
\hline \multirow{2}{*}{ Age } & \multirow{2}{*}{ \# Reactive } & \multirow{2}{*}{$\%$ Reactive } & \multicolumn{6}{|c|}{ \# Reactive according to antibody titer } \\
\hline & & & 64 & 128 & 256 & 512 & 1024 & 2048 \\
\hline Infant & $5 / 6$ & $83.33 \%$ & 2 & 1 & & 1 & & 1 \\
\hline Juvenile & $1 / 1$ & $100 \%$ & & & 1 & & & \\
\hline Young adult & $3 / 6$ & $50.00 \%$ & & 1 & 1 & & & 1 \\
\hline Adult & $2 / 2$ & $100.00 \%$ & & 2 & & & & \\
\hline Total & $11 / 15$ & $73.33 \%$ & 2 & 4 & 2 & 1 & & 2 \\
\hline \multicolumn{9}{|c|}{ Total } \\
\hline \multirow{2}{*}{ Age } & \multirow{2}{*}{ \# Reactive } & \multirow{2}{*}{$\%$ Reactive } & \multicolumn{6}{|c|}{ \# Reactive according to antibody titer } \\
\hline & & & 64 & 128 & 256 & 512 & 1024 & 2048 \\
\hline Infant & $16 / 22$ & $72.73 \%$ & 3 & 2 & 8 & 2 & & 1 \\
\hline Juvenile & $4 / 5$ & $80 \%$ & 1 & & 2 & & & 1 \\
\hline Young adult & $4 / 9$ & $44.44 \%$ & & 2 & 1 & & & 1 \\
\hline Adult & 17/21. & $80.95 \%$ & 3 & 11 & 2 & & & 1 \\
\hline Unkown & $1 / 1$ & $100.00 \%$ & & 1 & & & & \\
\hline Total & $42 / 58$ & $72.41 \%$ & 7 & 16 & 13 & 2 & & 4 \\
\hline
\end{tabular}

Age and sex information for the individual classified as unknown has been lost during experimental procedures.

SUCEN classifies BSF Risk Areas based on: 1. human use, 2. presence of Amblyomma ticks, and 3. seropositive results for spotted fever group Rickettsia in sentinel animals. Based on these criteria, the preliminary results led the agency to classify the gated community as a Risk Area for BSF transmission and propose measures to control the local tick population and transmission risks. The large and apparently increasing capybara population was considered a possible risk factor for transmission (SANGIONI et al., 2005; LABRUNA, 2009; DEL FIOL et al., 2010; LABRUNA, 2013; SOUZA et al., 2015), leading the competent environmental and health agencies (SMA and SUCEN) to take the decision to remove of all capybaras in the gated community as a measure to control local tick populations and BSF transmission risk. The competent agencies also decided for the complete fencing of parts of 
the gated community's perimeter that remained open, in order to avoid recolonization by other capybaras.

\section{Control of tick population and BSF risk}

\section{Capybara population removal}

The remaining parts of the gated community's perimeter had been properly fenced by November 6th, 2013, prior to the start of activities for removal of the local capybara population, as verified in an inspection by the SMA's wildlife department (CMFS Inspection Report n. 13/2013).

The capybara population survey conducted in October 2013 indicated 5 groups of capybaras and a total of 98 individuals inside the gated community, an increase over previous estimates, based on the October 2012 survey and the captures for serological tests earlier in 2013. Capybara removal took place between December 18th, 2013 and April 8th, 2014, resulting in the capture and euthanasia of 114 specimens (Table 3; see Table S.2 for detailed results). Based on the number of euthanized individuals and the results of noninvasive surveys at the end of each month between January 2014 and October 2014, we estimated a total of 115 capybaras living inside the gated community in October 2013, one of which seemingly remained alive at the end of the capybara removal activities, as indicated by the observation of some capybara tracks and feces in surveys performed between April and August 2014 (Table 3, Table S.2). Subsequent mammal monitoring activities have identified only indirect evidences of the species' presence in the study area, which we interpret as being produced by the same remaining individual.

Table 3 - Number of capybaras euthanized during management actions, remaining individuals observed at the end of each month, and estimated population size at the start and end of each month (i.e., before and after removal of capybaras)

\begin{tabular}{lcccc}
\hline & Euthanized & Observed (end of month) & Estimated (end of month) & Estimated (start of month) \\
\hline $.10 / 2013$ & 0 & 98 & 115 & 115 \\
$.11 / 2013$ & 0 & - & 115 & 115 \\
$.12 / 2013$ & 8 & - & 107 & 115 \\
$.01 / 2014$ & 40 & 39 & 67 & 107 \\
$.02 / 2014$ & 57 & 10 & 10 & 67 \\
$.03 / 2014$ & 7 & 2 & 3 & 10 \\
$.04 / 2014$ & 2 & tracks, feces & 1 & 3 \\
$.05 / 2014$ & 0 & tracks, feces & 1 & 1 \\
$.06 / 2014$ & 0 & tracks, feces & 1 & 1 \\
$.07 / 2014$ & 0 & tracks & 1 & 1 \\
$.08 / 2014$ & 0 & tracks & 1 & 1 \\
\hline
\end{tabular}

Table S.2 -Detailed results of capybara removal activities and capybara surveys performed during 2013/2014 and estimated remaining capybara population after removal on each date

\begin{tabular}{|c|c|c|c|c|c|c|}
\hline \multicolumn{7}{|c|}{ Euthanized } \\
\hline & Males & Females & Infants & Total & Observed & Estimated \\
\hline .10 .2013 & & & & & 98 & 115 \\
\hline 18.12.2013 & 2 & 6 & 0 & 8 & & 115 \\
\hline 8.1 .2014 & 1 & 2 & 0 & 3 & & 107 \\
\hline 9.1 .2014 & 3 & 11 & 4 & 18 & & 104 \\
\hline 13.1 .2014 & 3 & 1 & 1 & 5 & & 86 \\
\hline 20.1 .2014 & 0 & 1 & 0 & 1 & & 81 \\
\hline 23.1 .2014 & 0 & 4 & 0 & 4 & & 80 \\
\hline 24.1 .2014 & 0 & 2 & 1 & 3 & & 76 \\
\hline
\end{tabular}


Table S.2 - Detailed results of capybara removal activities and capybara surveys performed during 2013/2014 and estimated remaining capybara population after removal on each date

(continued)

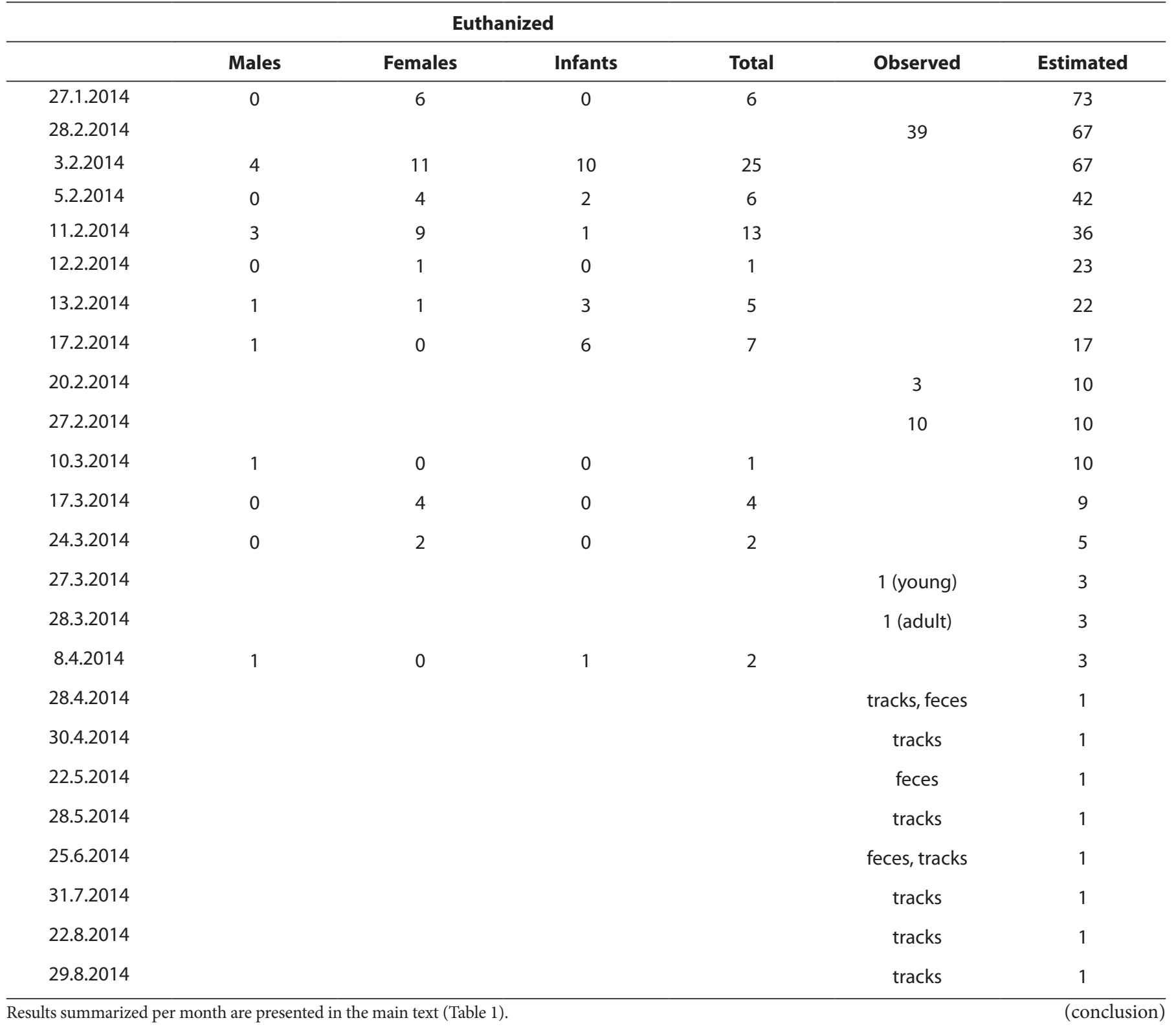

The demographics of the population present in the gated community based on euthanized individuals are presented in Table 4. The estimated population of 115 individuals represents a density of $11.5 \mathrm{ind} / \mathrm{km}^{2}$, similar to that seen in natural areas in the Brazilian Pantanal (SCHALLER; CRAWSHAW JUNIOR, 1981; ALHO; RONDON, 1987), and therefore remarkably high considering the characteristics of the study area. The removed population consisted of $74.56 \%$ adults and $25.44 \%$ infants, a lower number of infants in comparison to the results for 2013, as seen above. The sex ratio of the removed population was 1:3.25 (males/females), a female predominance greater than the one indicated by captures in 2013, and greater even than the full range of sex ratios seen in all studies mentioned by Moreira et al. (2013).
Table 4-Demographic characteristics of the resident population of capybaras in the study area during management activities to control BSF risk

\begin{tabular}{llcccc}
\hline & & $\#$ & age $\%$ & sex $\%$ & Sex rate \\
\hline adults & total & 85 & $74.56 \%$ & & $1: 3.25$ \\
& male & 20 & & $23.53 \%$ & \\
& female & 65 & & $76.47 \%$ & \\
infants & total & 29 & $25.44 \%$ & & \\
\hline
\end{tabular}

\section{Tick population analysis}

The dynamics of A.sculptum adults, nymphs and larvae at each of the 10 sampling points in the gated community between February 2014 and November 2015 are shown in Figure 2. Eight adult specimens of A. dubitatum have been recorded (3.1\% of all adult ticks) in sampling points 2,4 , 6 and 8; all further analyses focus only on A. sculptum. 


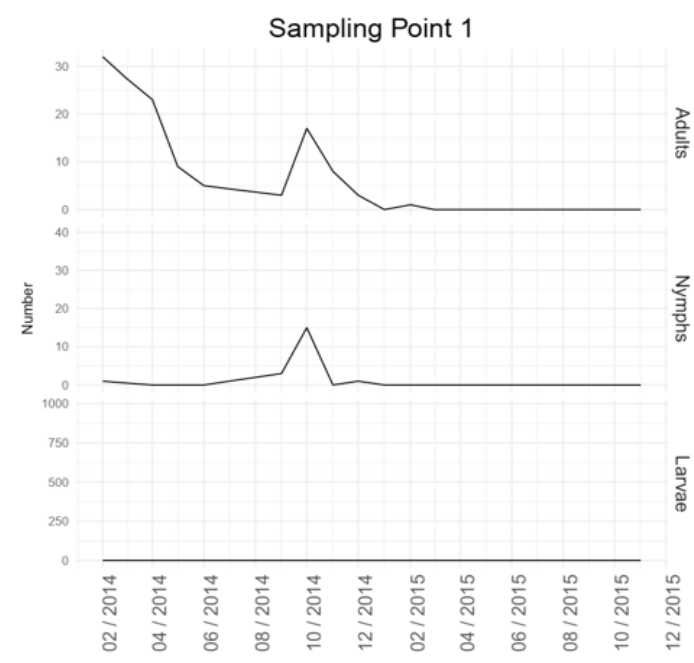

Sampling Point 3

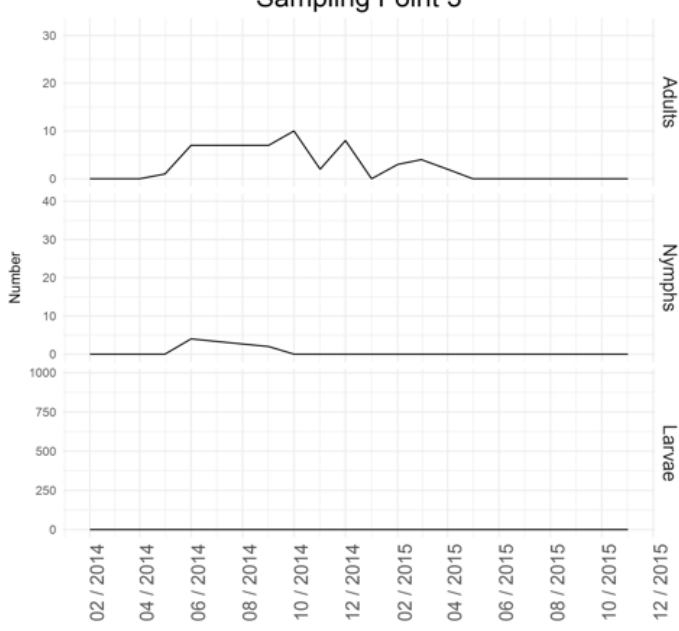

Sampling Point 5

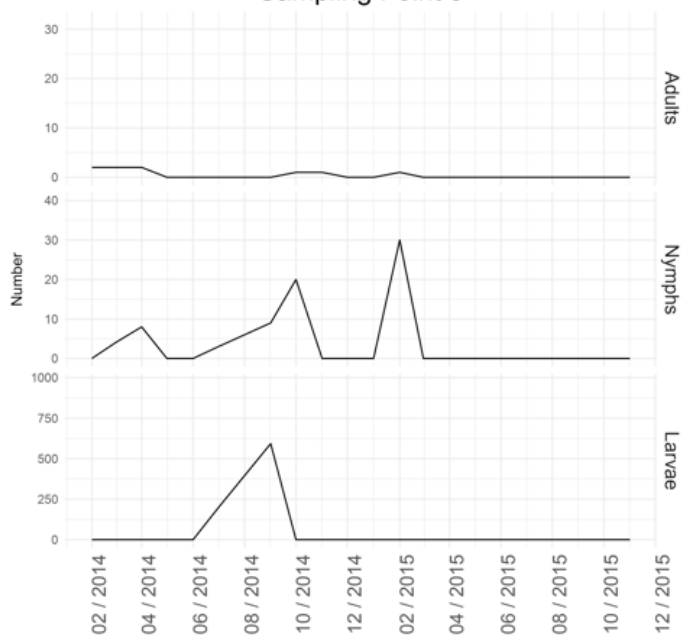

Sampling Point 2

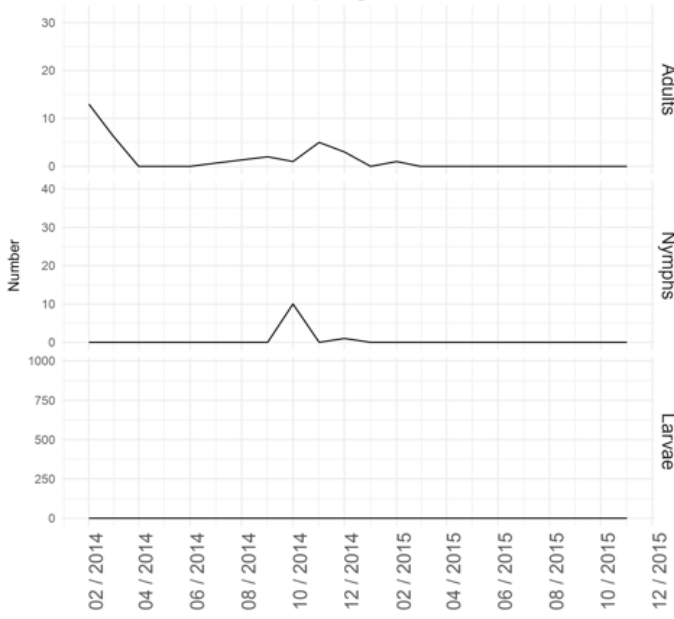

Sampling Point 4

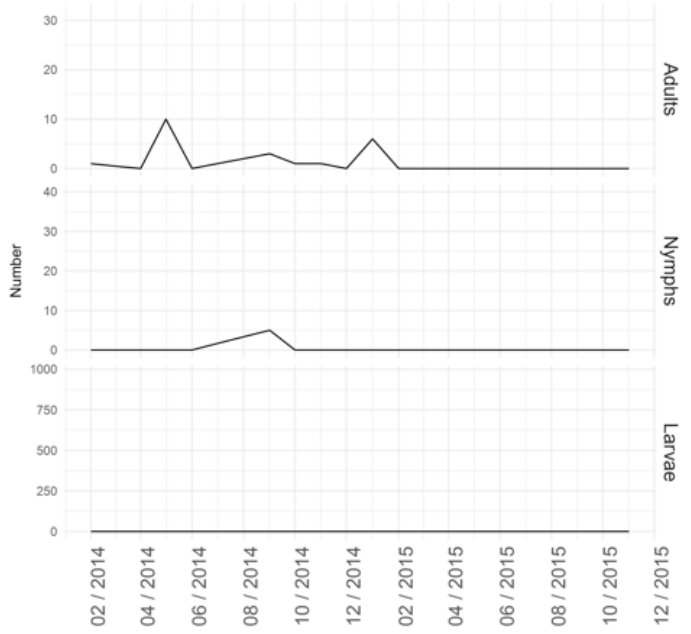

Sampling Point 6

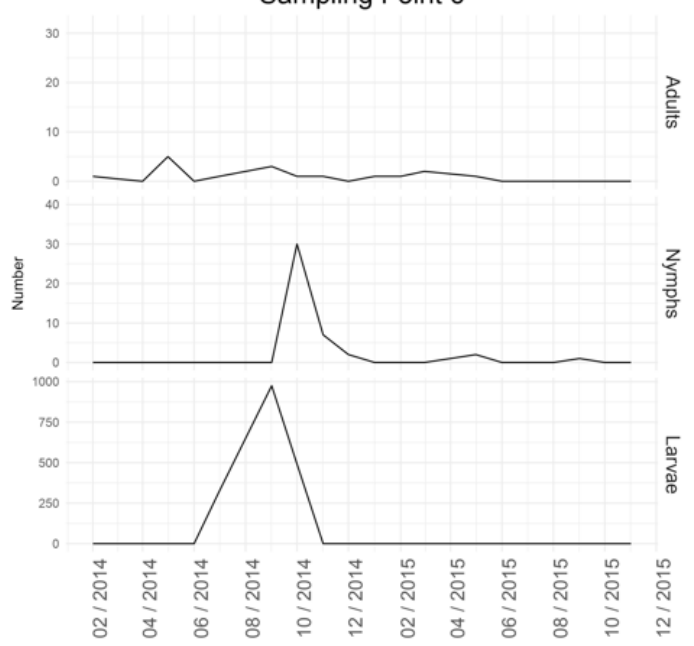

Figure 2 - Dynamics of free-living Amblyomma sculptum adults, nymphs and larvae at the 10 sampling points studied in a gated community in Bragança Paulista (SP, Brazil), between February 2014 and November 2015 

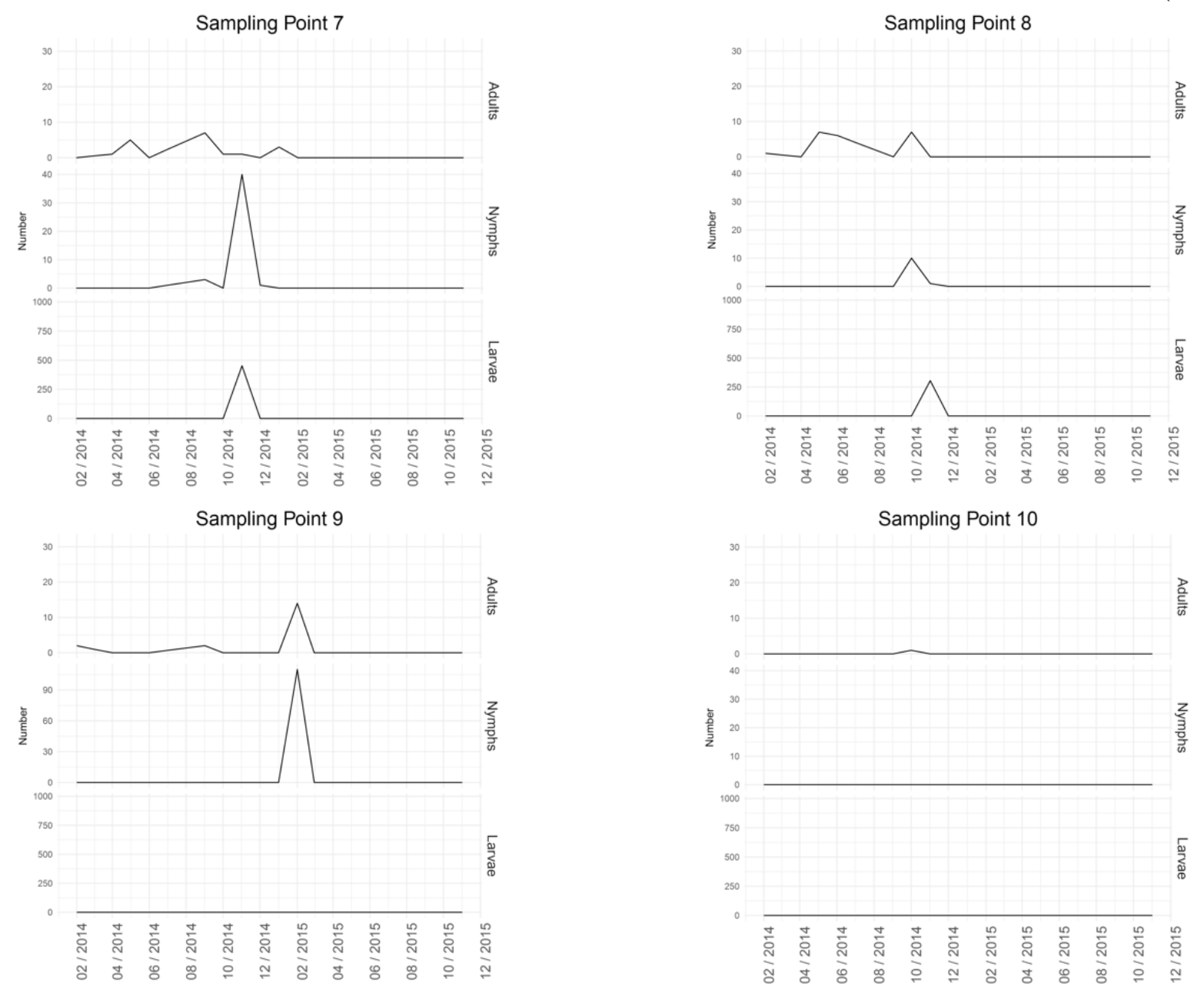

Figure 2 - Dynamics of free-living Amblyomma sculptum adults, nymphs and larvae at the 10 sampling points studied in a gated community in Bragança Paulista (SP, Brazil), between February 2014 and November 2015

The location of the sampling points is shown in Figure 1, above.

(conclusion)

Ten or more adult ticks were observed in at least one month in sampling points 1, 2, 3, 4 and 9, located near or at the margins of the two lakes farthest from the gated community's equestrian club (see Figure 1). The largest number of ticks was recorded at sampling point 1 during the first survey, in February 2014. Larvae have been identified at four sampling points $(5,6,7$ and 8$)$, with population bursts between July 2014 and September or October 2014 at sampling points 5, and 6 and in November 2014 at sampling points 7 and 8 . Increases in the population of nymphs were registered in October and November (sampling points 1, 2, 6, 7 and 8), but also earlier (especially at sampling point 5); a localized burst in the number of nymphs occurred in February 2015 at sampling points 5 and 9.

The dynamics of adults shows large numbers of ticks during the first months of 2014, especially at sampling points 1 and 2, and population surges around October 2014 at some sampling points, often associated with increased numbers of nymphs in the same or in the preceding month.
The bursts in nymph numbers in February 2015 led to a transient increase in adult ticks at sampling point 9, but not 5. While some coupling of the dynamics of tick stages did occur at some sampling points, this does not seem sufficient to explain local tick population dynamics, suggesting the existence of tick flow between areas in the gated community, possibly carried by other hosts present in the area (e.g., opossums, other mammals, and possibly birds - PEREIRA; LABRUNA, 1998; LABRUNA et al., 2001; LABRUNA et al., 2002b; GUGLIELMONE et al., 2003; LABRUNA et al., 2005; PEREZ et al., 2008), which justifies using the sum of results for the whole study area as a basis of statistical analyses. Also noteworthy is the almost complete absence of all stages of Amblyomma sculptum after February 2015.

Figure 3 shows the dynamics of A. sculptum adults, nymphs and larvae populations in the gated community for the 2-year period between January 2014 and December 2015, using the closest values to estimate the population between January 2014 and December 2015 (see Methods), 
as well as estimated Seasonal and Trend components for each tick stage. The Trend component for adults shows a monotonic decrease between July 2014 and June 2015, while no clear trend can be identified for nymphs and larvae. The estimated seasonal component for larvae suggests a pulse approximately between August and October, later than that found in previous studies (LABRUNA, 2000; LABRUNA et al., 2002a), while the seasonal component for nymphs and adults shows two rather close peaks in October and February, a behavior that seems at odds with previous studies indicating that the species has an 1-year generation pattern (SERRA-FREIRE, 1982; SOUZA, 1990;
OLIVEIRA et al., 2000; LABRUNA et al., 2002a). It is possible that the close peaks may actually correspond to a single peak in spring and summer months, disrupted midway by population decreases caused by capybara removal and the other management measures then being undertaken. The fact that the seasonal peak for nymphs and for adults occurred during spring and summer and not during fall and winter months, as seen in previous studies (SERRA-FREIRE, 1982; SOUZA, 1990; OLIVEIRA et al., 2000; LABRUNA et al., 2002a) is harder to explain, but could also be related to a disruption of population dynamics linked to the ongoing management measures.
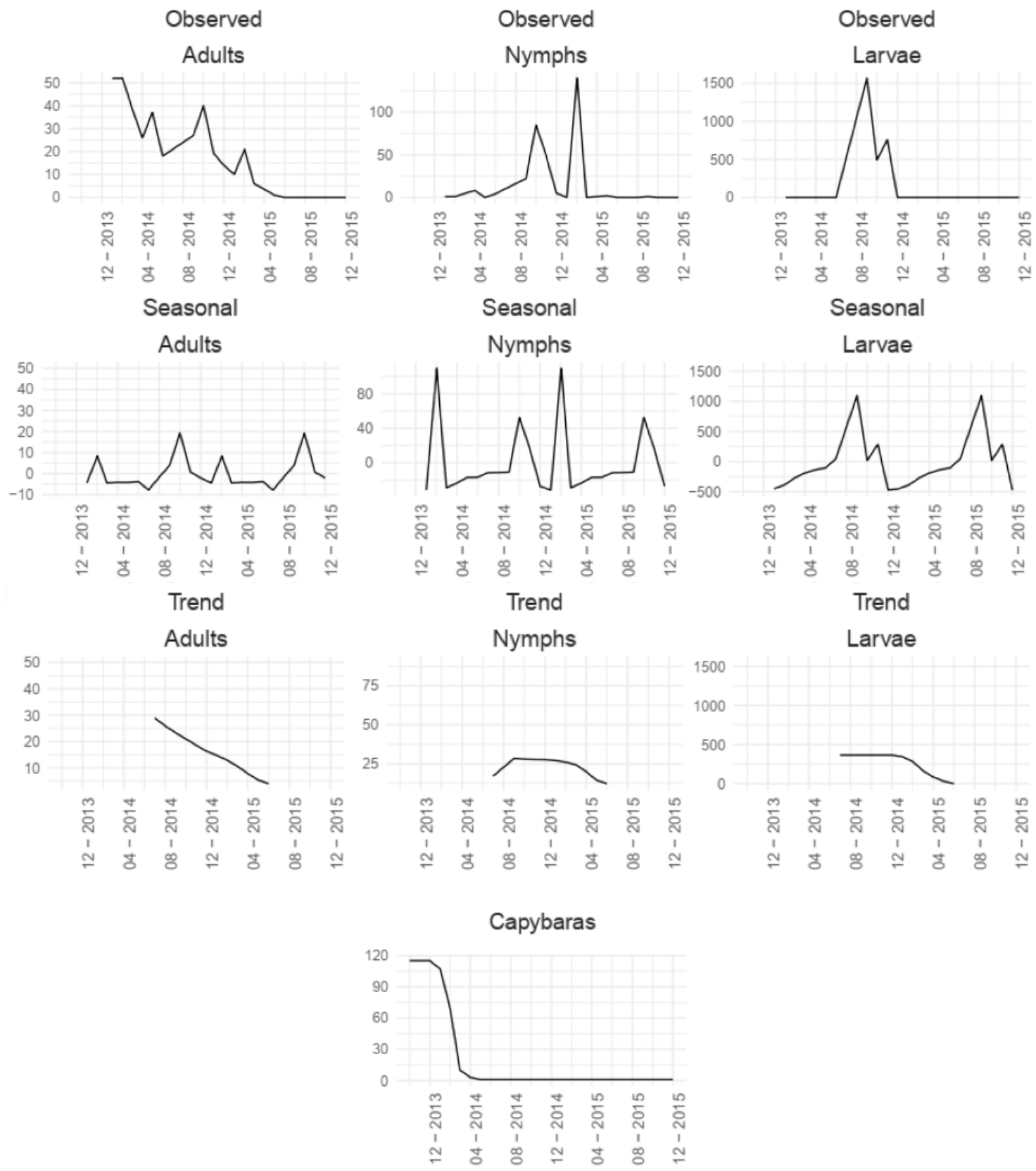

Figure 3 - Dynamics of free-living Amblyommasculptum adults, nymphs and larvae in a gated community in Bragança Paulista (SP, Brazil), between January 2014 and December 2015 (top row) and its decomposition into Seasonal (second row) and Trend (third row) components

The capybara population during the same period is shown at the bottom, for comparison. 
It is worth noting that the population for all tick stages reached virtually zero at all times after June 2015 , at the latest (earlier for nymphs and larvae), and that population bursts expected during 2015 based on estimated seasonal components seemingly did not occur. This may be interpreted as an indication of effective control of the tick population in the study area, preventing normal continuation of the species' seasonal cycles.

The results of regressions of tick stage populations on time (months) with ARMA errors are shown in Table 5, below. The results indicate a statistically significant reduction in the number of adult ticks over time between February 2014 and November 2014, corroborating the downward trend in the adult tick population suggested by the decomposition of the time series (see above). The actual number of adult ticks registered during surveys reaches zero in June 2015, as mentioned above. These results seem to support the effectiveness of the management measures taken in controlling the environmental tick burden. No significant Autoregression (AR) or Moving-Average (MA) parameters were identified for adult ticks, suggesting that current population and population changes in one month did not significantly affect population size at subsequent times during the studied period.

Table 5 - Results of regressions with errors following an automatically fit ARMA model for Adults, Nymphs and Larvae of A. sculptum, using data from February 2014 to November 2014

\begin{tabular}{lccc}
\hline & Intercept & Time & AR \\
\hline Adults & $41.20 \pm 6.10^{* * *}$ & $-2.17 \pm 0.47^{* * *}$ & - \\
Nymphs & - & $0.95 \pm 1.11$ & - \\
Larvae & - & $7.13 \pm 27.11$ & $0.67 \pm 0.29^{* * *}$ \\
\hline
\end{tabular}

The values represent the estimated parameter $\pm 95 \%$ confidence interval (standard deviation $\times 1.96$ ).

Significance: ${ }^{* *}(\mathrm{p}<0.001) ;{ }^{* *}(\mathrm{p}<0.01) ;{ }^{*}(\mathrm{p}<0.05)$

Table 6-AIC, $\Delta$ AIC and Akaike weights (w) for linear regressions of adult tick population on capybara population with time gaps between 0 and 15 months

\begin{tabular}{cccc}
\hline gap (months) & AIC & DAIC & W \\
\hline 0 & 180.88 & 19.55 & 0.0000 \\
1 & 177.83 & 16.49 & 0.0001 \\
2 & 177.15 & 15.82 & 0.0001 \\
3 & 175.21 & 13.88 & 0.0003 \\
4 & 175.13 & 13.80 & 0.0004 \\
5 & 175.90 & 14.57 & 0.0002 \\
6 & 175.43 & 14.10 & 0.0003 \\
7 & 173.23 & 11.90 & 0.0009 \\
8 & 166.80 & 5.47 & 0.0231 \\
9 & 161.37 & 0.04 & 0.3497 \\
\hline
\end{tabular}

Table 6-AIC, $\Delta$ AIC and Akaike weights (w) for linear regressions of adult tick population on capybara population with time gaps between 0 and 15 months

(continued)

\begin{tabular}{cccc}
\hline gap (months) & AIC & AAIC & W \\
\hline 10 & 161.33 & 0.00 & 0.3573 \\
11 & 163.94 & 2.61 & 0.0970 \\
12 & 163.62 & 2.28 & 0.1140 \\
13 & 165.27 & 3.94 & 0.0498 \\
14 & 169.49 & 8.16 & 0.0060 \\
15 & 173.87 & 12.54 & 0.0007 \\
\hline & & & (conclusion)
\end{tabular}

No significant parameters were identified for nymphs, suggesting that the temporal dynamics for this stage at the gated community during the studied period can be understood as rapid transient population pulses with no significant influence on the nymph population over the subsequent months. This suggests a short survival time of free-living nymphs in the area. Using the maximum value of the nymph time series for January 2014 leads to the identification of a non-zero intercept, but does not otherwise change the interpretation of results (see Table S.1). Finally, the ARMA regression for larvae identified a first-order autoregressive (AR) model, indicating that population increases for this stage persist for some time, and therefore suggesting longer survival of free-living ticks in this stage. The first-order AR parameter suggests a persistence of at least 1 month, less than that described for free-living larvae by Labruna (2000) in Pirassununga (state of São Paulo), perhaps also a result of the ongoing management measures in the area analyzed here. Using the maximum value of the larvae time series for January 2014 creates an unlikely off-season peak (see Figure 3 above), and leads to the identification of a non-zero intercept and a large reduction in the strength of the AR parameter.

The Akaike weights of linear models using capybara population with different time gaps as a predictor of adult tick population suggest that reduction of the capybara population most likely has an effect on adult tick population after a gap of approximately 9 (probability of $34.97 \%$ ) or 10 months (probability of 35.73\%) (Table 6). The effect of capybara population reduction on the adult population of A. sculptum has estimated slopes of $0.239 \pm 0.067$ (gap of 9 months) and $0.238 \pm 0.066$ (10 months), is highly significant ( $\mathrm{p}<0.001$ ), and explains over $70 \%$ of total variation in both cases $\left(R^{2}=0.7133\right.$ and 0.7135 for gaps of 9 and 10 months, respectively). While this effect size may be overestimated as a direct measure of capybara removal, as it is conflated 
here with the effects of the other simultaneous management measures (e.g., grass mowing, use of acaricides), this result strongly suggests the effectiveness of the set of measures taken in reducing tick burden (and consequently BSF risk), and also that the exclusion of capybaras as the primary host for A. sculptum has likely played an important role for this reduction in the study area.

Previous studies mention that free-living adults of A. sculptum may remain viable in the environment for approximately 1 year (ROHR, 1909), and for that reason Labruna (2013) suggested that results of primary host exclusion on tick populations and BSF risk should only be expected after 1 or 2 years. The time gap of 9-10 months between primary host exclusion and tick population reduction identified here can therefore be considered short. This relatively rapid effect is possibly explained by the simultaneous use of other management measures further reducing the population of free-living ticks in the environment.

\section{Serological tests}

The results of the serological test performed on horses kept at the gated community's stud farm in December 2014 is shown in Table 1, along with the results of the previous test conducted in September 2013. The general rickettsial seroprevalence in horses decreased from $53.05 \%$ to $35 \%$, and the antibody titers of reactive horses likewise became lower (Figure 4). Titers of 1024 were not observed in any horse in December 2014 (compared to three animals in 2013), and only two animals had titers of 512 (compared to five in 2013). The non-parametric Wilcoxon-MannWhitney test found a significant, albeit small reduction in titers between September 2013 and December 2014 $(\mathrm{p}=0.0099, \mathrm{r}=0.206)$.

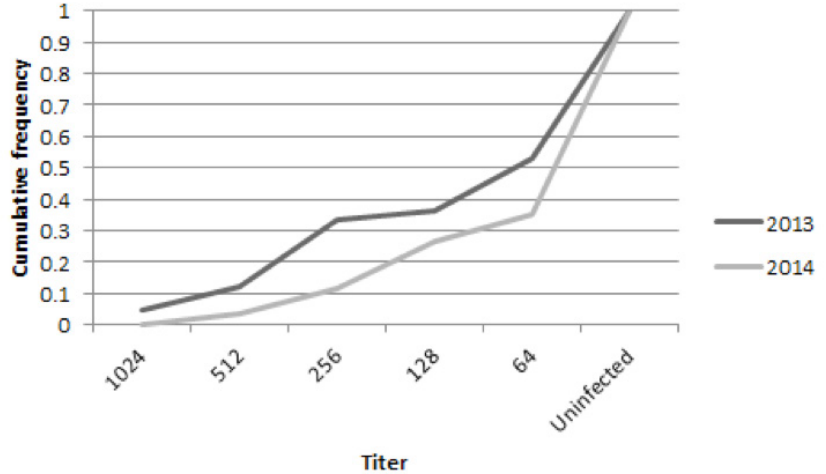

Figure 4-Cumulative frequency of serology results for Rickettsia rickettsii in horses kept at the gated community's stud farm

Note a general reduction in antibody titers between tests conducted in September 2013 and December 2014

When considering only the 38 horses tested both in 2013 and 2014, the majority of the horses found to be seropositive in 2013 had lower antibody titers in 2014 (12 of 21 previously seropositive horses, or $57.14 \%$ ). The titers of 9 previously seropositive horses (42.86\%) had remained equal in December 2014, and no horses had higher titers than found in the previous test (Table 7), further suggesting a reduction of BSF risk in the study area. In a recent study by Ueno et al. (2016) in which four horses were experimentally infected with $R$. rickettsii, antibody persistence varied between approximately 6 months and over 2 years after the initial infection. Therefore, it is expected that some horses would remain seropositive for a relatively long time after a reduction of the local tick burden and BSF transmission risk. The non-parametric Wilcoxon signed-rank test identified a significant reduction in the $R$. rickettsii antibody titers of horses tested in both September 2013 and December 2014, with an effect size of medium to large magnitude $(\mathrm{p}<0.0001 ; \mathrm{r}=0.56)$.

Table 7 - Comparison of Rickettsia rickettsii antibody titers identified in indirect immunofluorescence assays (IFA) conducted in horses kept at the gated community's stud farm, for horses tested in both October 2013 and December 2014

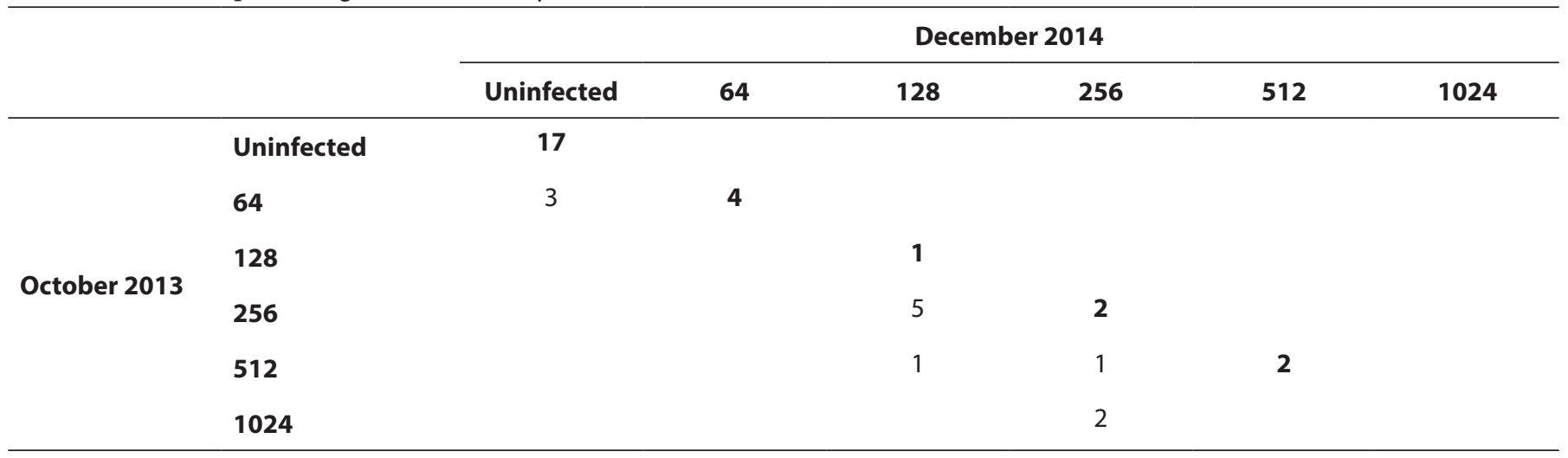

Values in bold across the diagonal represent animals with identical titers in both tests; values below the diagonal represent animals which have undergone a reduction in antibody titers between both dates. 
The significant reduction in $R$. rickettsii antibody titers of infected horses may be considered a further indication that the management measures taken, and particularly the exclusion of the local population of capybaras, were effective in reducing the local BSF transmission risk. The reduction in titers also seems to indicate that capybaras were in fact the main amplifying host for $R$. rickettsii in the gated community, and that other potential amplifying hosts (e.g. opossums - Didelphis sp. - HORTA et al., 2009) apparently do not play this role in the study area.

Further serological tests in the area after 2015 had not been conducted at the time of writing. More recent tests of the sentinel animals would be an important addition to this study, as a verification of the effectiveness of continued management actions for controlling BSF risk at the study area in the medium term, and may be disclosed as a short case report if and when they become available.

\section{Conclusion}

In this study we reported the factors leading to the identification of a gated community located in an area of the state of São Paulo as a Risk Area for BSF, including an increasing resident capybara population with high rickettsial seroprevalence, and analyzed the effectiveness of a set of management actions taken to control the tick burden and BSF transmission risk, including removal of the local capybara population (apparently acting as amplifying hosts in the area) and other measures to control parasitic and free-living populations of Amblyomma ticks. The results of tick population analyses and serology tests indicate that the management measures were effective, greatly reducing the environmental tick burden in the study area and significantly lowering BSF transmission risk. This study provides evidence that removing local capybara populations in enclosed BSF Risk Areas with high capybara population densities and high Amblyomma tick load may be an appropriate action to reduce tick load and BSF transmission risk, provided that the capybara population is effectively removed and that this measure will not jeopardize the survival of capybara populations at the regional level.

\section{Conflicts of interest}

C. A. Dias and D. B. Vasquez are employees of the gated community where the case study was performed. A. A. Kunyi, M. S. Nardi, P. M. Leonis, V. Arruda, S. Pelegrini, H. S. Silva and L. P. Godoy are employed by the environmental consulting company hired by the gated community studied to perform fauna monitoring and other environment-related services. The other authors declare no competing interests.

\section{Acknowledgments}

We would like to extend our thanks to Dr. Marcelo Labruna and Dr. Adriano Pinter for suggestions regarding the publication of this study. A. A. Kuniy also thanks Dr. Adriano Pinter for help identifying tick species and Dr. Marcelo Labruna for providing access to his laboratory during earlier tick monitoring studies in the study area, performed between 2004 and 2006.

\section{Author contributions}

Study conceptualization: A. A. Kunyi; Capybara and mammal monitoring: C. A. Dias., M. S. Nardi, P. M. Leonis, V. Arruda, S. Pelegrini, H. S. Silva and L. P. Godoy; Monitoring of capybara removal activities: C. A. Dias., M. S. Nardi, P. M. Leonis, V. Arruda, S. Pelegrini, H. S. Silva and L. P. Godoy; Preliminary analysis of capybara population data: C. A. Dias., M. S. Nardi, P. M. Leonis, V. Arruda, S. Pelegrini, H. S. Silva and L. P. Godoy; Tick monitoring: C. Souza and F. C. M. Uchoa; A. A. Kunyi in earlier surveys; Preliminary analysis of tick population data: C. Souza and F. C. M. Uchoa; A. A. Kunyi in earlier surveys; Serological tests: C. Souza and F. C. M. Uchoa; Data organization: A. A. Kunyi, T. G. Luiz, M. S. Pereira, D. B. Vasquez and T. M. G. Zahn; Drafting of $1^{\text {st }}$ version of manuscript: A. A. Kunyi, T. G. Luiz and M. S. Pereira; Data analysis and computer code: T. M. G. Zahn; Revised manuscript: A. A. Kunyi, D. B. Vasquez and T. M. G. Zahn.

\section{References}

ALHO, C. J. R.; RONDON, N. L. Habitats, population densities, and social structure of capybaras (Hydrochaeris hydrochaeris, Rodentia) in the Pantanal, Brazil. Revista Brasileira de Zoologia, v. 4, n. 2, p. 139-149, 1987. doi: 10.1590/S0101-81751987000200006.
ANDERSON, D. R.; BURNHAM, K. P.; WHITE, G. C. Comparison of Akaike information criterion and consistent Akaike information criterion for model selection and statistical inference from capture-recapture studies. Journal of Applied Statistics, v. 25,n. 2, p.263-282, 1998. doi: 10.1080/02664769823250. 
ANGERAMI, R. N.; RESENDE, M. R.; FELTRIN, A. F. C.; KATZ, G.; NASCIMENTO, E. M. M.; STUCCHI, R. S. B.; SILVA, L. J. Brazilian spotted fever: a case series from endemic area in Southeastern Brazil. Annals of the New York Academy of Sciences, v. 1078, n. 1, p. 252-254, 2006. doi: 10.1196/annals.1374.044.

ARAGÃO, H. Ixodidas brasileiros e de alguns paizes limitrophes. Memórias do Instituto Oswaldo Cruz, v. 31, n. 4, p. 759-843, 1936. doi: 10.1590/S0074-02761936000400004.

BARROS E SILVA, P. M. R.; PEREIRA, S. C.; FONSECA, L. X.; MANIGLIA, F. V. P.; OLIVEIRA, S. V.; CALDAS, E. P. Febre maculosa: uma análise epidemiológica dos registros do sistema de vigilância do Brasil. Scientia Plena, v. 10, n. 4, 2014. Available from: <https://www. scientiaplena.org.br/sp/article/view/1758/955>.

BRASIL. Lei n 9.605, de 12 de fevereiro de 1998. Dispõe sobre as sanções penais e administrativas derivadas de condutas e atividades lesivas ao meio ambiente, e dá outras providências. Diário Oficial da União, Brasília, DF, 13 fev. 1998. Seção 1, p. 1.

BRASIL. Lei no 5.197, de 3 de janeiro de 1967. Dispõe sobre a proteção à fauna e dá outras providências. Diário Oficial da União, Brasília, DF, 5 jan. 1967. Seção 1, p. 177.

BRASIL. Ministério da Saúde. Portaria no 1.943, de 18 de outubro de 2001. Define a relação de doenças de notificação compulsória para todo território nacional. Diário Oficial da União, n. 204, 2001. Seção 1, p. 35.

BURNHAM, K. P.; ANDERSON, D. R. Kullback-Leibler information as a basis for strong inference in ecological studies. Wildlife Research, v. 28, p. 111-119, 2001. doi: 10.1071/WR99107.

BURNHAM, K. P.; ANDERSON, D. R. Model selection and multimodel inference: a practical informationtheoretic approach. New York: Springer-Verlag, 2002.

CFMV - Conselho Federal de Medicina Veterinária (Brasil). Resolução no 1000, de 11 de maio de 2012. Dispõe sobre procedimentos e métodos de eutanásia em animais e dá outras providências. Brasília: CFMV, 2019. Available from: <http://portal.cfmv.gov.br/lei/index/ id/326>. Viewed: 8 Feb. 2019.
DEL FIOL, F. S., JUNQUEIRA, F. M., ROCHA, M. C. P., TOLEDO, M. I., BARBERATO FILHO, S. A. A febre maculosa no Brasil. Revista Panamericana de Salud Pública, v. 27, n. 6, p. 461-466, 2010. Available from: <https://scielosp.org/pdf/ rpsp/2010.v27n6/461-466/pt>. Viewed: Dec. 14th, 2018.

GAlvÃO, M. A. M.; CALIC, S. B.; CHAMONE, C. B.; MAFRA, C. L.; CESARINO FILHO, C.; OLANO, J. P.; WALKER, D. H. Spotted fever rickettsiosis in Coronel Fabriciano, Minas Gerais State. Revista da Sociedade Brasileira de Medicina Tropical, v. 36, n. 4, p. 479-481, 2003. doi: 10.1590/S0037-86822003000400008.

GUGLIELMONE, A. A.; ESTRADA-PEÑA, A.; KEIRANS, J. E.; ROBINS, R. G. Ticks (Acari: Ixodida) of the Neotropical Zoogeographic Region. Utrecht (NL): International Consortium on Ticks and Tick-borne Diseases, 2003. 173 p.

HERRERA, E. A. Capybara social behavior and use of space: patterns and processes. In: MOREIRA, J. R., HERRERA, E. A., FERRAZ, K. M. P. M. B., MACDONALD, D. W. (Ed.). Capybara: biology, use and conservation of an exceptional neotropical species. New York: Springer, 2013. p. 371-383.

HOLLANDER, M.; WOLFE, D. A. Nonparametric statistical methods. 2. ed. New York: John Wiley \& Sons, 1999.

HORTA, M. C.; MORAES-FILHO, J.; CASAGRANDE, R. A.; SAITO, T. B.; ROSA, S. C.; OGRZEWALSKA, R. M.; MATUSHIMA, E. R.; LABRUNA, M. B. Experimental infection of opossums Didelphis aurita by Rickettsia rickettsii and Evaluation of the transmission of the infection to ticks Amblyomma cajennense. Vector-Borne and Zoonotic Diseases, v. 9, n. 1, p. 109-117, 2009. doi: 10.1089/vbz.2008.0114.

HOTHORN, T.; HORNIK, K.; VAN DE WIEL, M. A.; ZEILEIS, A. Implementing a class of permutation tests: the coin package. Journal of Statistical Software, v. 28, n. 8, p. 1-23, 2008. doi: 10.18637/ jss.v028.i08.

HYNDMAN, R. J.; KHANDAKAR, Y. Automatic time series forecasting: the forecast package for R. Journal of Statistical Software, v. 27, n. 3, p. 1-22, 2008. doi: 10.18637/jss.v027.i03.

IBAMA (Instituto Brasileiro do Meio Ambiente e dos Recursos Naturais Renováveis). Diagnóstico populacional da capivara. São Paulo: IBAMA, 2006. 8 p. 
KATZ, G.; CAMARGO-NEVES, V. L. F.; ANGERAMI, R. N.; NASCIMENTO, E. M. M.; COLOMBO, S. Situação epidemiológica e importância da febre maculosa no estado de São Paulo. Boletim Epidemiológico Paulista, v. 6, n. 69, p.4-13, 2009. Available from: <http://periodicos.ses.sp.bvs.br/scielo. php?script=sci_arttext\&pid=S1806-42722009000900001\&ln $\mathrm{g}=\mathrm{pt \& nrm}=\mathrm{iss}>$. Viewed: Dec. 14th, 2018.

\section{LABRUNA, M. B. Aspectos da biologia e epidemiologia} dos carrapatos de eqüinos no estado de São Paulo. 2000. 76 p. Tese (Doutorado em Ciências) - Universidade de São Paulo, Faculdade de Medicina Veterinária e Zootecnica, São Paulo, 2000.

LABRUNA, M. B. Ecology of Rickettsia in South America. Annals of the NY Academy of Science, v. 1166, n. 1, p. 156-166, 2009. doi: 10.1111/j.1749-6632.2009.04516.x.

LABRUNA, M. B. Brazilian spotted fever: the role of capybaras. In: MOREIRA, J. R.; HERRERA, E. A.; FERRAZ, K. M. P. M. B.; MACDONALD, D. W. (Ed.). Capybara: biology, use and conservation of an exceptional neotropical species: New York: Springer, 2013. p. 371-383.

LABRUNA, M. B.; CAMARGO, L. M. A.; TERRASSINI, F. A.; FERREIRA, F.; SCHUMAKER, T. T. S.; CAMARGO, E. P. Ticks (Acari: Ixodidae) from the state of Rondônia, western Amazon, Brazil. Systematic and Applied Acarology, v. 10, n. 1, p. 17-32, 2005. doi: 10.11158/saa.10.1.4.

LABRUNA, M. B.; KASAI, N.; FERREIRA, F.; FACCINI, J. L. H.; GENNARI, S. M. Seasonal dynamics of ticks (Acari: Ixodidae) on horses in the state of São Paulo, Brazil. Veterinary Parasitology, v. 105, n. 1, p. 65-77, 2002a. doi: 10.1016/S0304-4017(01)00649-5.

LABRUNA, M. B.; KERBER, C. E.; FERREIRA, F.; FACCINI, J. L. H.; DE WAAL, D. T.; GENNARI, S. M. Risk factors to tick infestations and their occurrence on horses in the state of São Paulo, Brazil. Veterinary Parasitology, v. 97, n. 1, p. 1-14, 2001. doi: 10.1016/S03044017(01)00387-9.

LABRUNA, M. B.; PAULA, C. D.; LIMA, T. F.; SANA, D. A. Ticks (Acari: Ixodidae) on wild animals from the Porto-Primavera hydroelectric power station area, Brazil.
Memórias do Instituto Oswaldo Cruz, v. 97, n. 8, p. 11331136, 2002b. doi: 10.1590/S0074-02762002000800012.

LIMA, V. L. C.; SOUZA, S. S. L.; SOUZA, C. E.; VILELA, M. F. G.; PAPAIORDANOU, P. M. O.; DEL GUÉRCIO; V. M. F. Situação da febre maculosa na região Administrativa de Campinas, São Paulo, Brasil. Cadernos de Saúde Pública, v. 19, n. 1, p. 331-334, 2003. doi: 10.1590/S0102311X2003000100038.

MANGIAFICO, S. Summary and analysis of Extension Program Evaluation in R. (version 1.13.5). New Brunswick, NJ: Rutgers, 2016. Available from: <http://rcompanion. org/documents/RHandbookProgramEvaluation.pdf $>$. Viewed: June 16th, 2018.

MANGIAFICO, S. Rcompanion: functions to support extension education program evaluation. $\mathrm{R}$ package version 1.13.2. Vienna: CRAN, 2018. Available from: <https://cran.r-project.org/web/packages/rcompanion/ index.html>. Viewed: June 16th, 2018.

MARTINS, T. F. Estudo do complexo Amblyomma cajennense no Brasil. 2014. 113 f. Tese (Doutorado em Ciências) - Faculdade de Medicina Veterinária e Zootecnia, Universidade de São Paulo, São Paulo, 2014.

MOREIRA, J. R.; WIEDERHECKER, H.; FERRAZ, K. M. P. M. B.; ALDANA-DOMÍNGUEZ, J.; VERDADE, L. M.; MACDONALD, D. W. Capybara demographic traits. In: MOREIRA, J. R., HERRERA, E. A., FERRAZ, K. M. P. M. B., MACDONALD, D. W. (Ed.). Capybara: biology, use and conservation of an exceptional neotropical species. New York: Springer, 2013. p. 371-383.

NAVA, S.; BEATI, L.; LABRUNA, M. B.; CÁCERES, A. G.; MANGOLD, A. J.; GUGLIELMONE, A. A. Reassessment of the taxonomic status of Amblyomma cajennense (Fabricius, 1787) with the description of three new species, Amblyomma tonelliae n. sp., Amblyomma interandinum n. sp. and Amblyomma patinoi n. sp., and reinstatement of Amblyomma mixtum Koch, 1844 and Amblyomma sculptum Berlese, 1888 (Ixodida: Ixodidae). Ticks and Tick-borne Diseases, v. 5, n. 3, p. 252-276, 2014. doi: 10.1016/j.ttbdis.2013.11.004.

OLIVEIRA, P. R. Amblyomma cajennense (Fabricius, 1787) (Acari: Ixodidae): avaliação de técnicas para o 
estudo de dinâmica populacional e biotecnologia. 1998 . 97 f. Tese (Doutorado em Ciência Animal) - Escola de Veterinária, Universidade Federal de Minas Gerais, Belo Horizonte, 1998.

OLIVEIRA, P. R.; BORGES, L. M. F.; LOPES, C. M. L.; LEITE, R. C. Population dynamics of the free living stages of Amblyomma cajennense (Fabricius, 1787) (Acari: Ixodidae) on pasture of Pedro Leopoldo, Minas Gerais state, Brazil. Veterinary Parasitology, v. 92, n. 4, p. 295-301, 2000. doi: 10.1016/S0304-4017(00)00322-8.

PEREIRA, M. C.; LABRUNA, M. B. Febre maculosa: aspectos clínico-epidemiológicos. Clínica Veterinária, v. 3, p. 19-23, 1998.

PEREZ, C. A.; ALMEIDA, A. F.; ALMEIDA, A.; CARvalho, V. H. B.; BAlestrin, D. C.; GUIMARÃES, M. S.; COSTA, J. C.; RAMOS, L. A.; ARRUDA-SANTOS, A. D.; MÁXIMO-ESPÍNDOLA, C. P.; BARROS-BATTESTI, D. M. Carrapatos do gênero Amblyomma (Acari: Ixodidae) e suas relações com os hospedeiros em área endêmica para febre maculosa no estado de São Paulo. Revista Brasileira de Parasitologia Veterinária, v. 17, n. 4, p. 210-217, 2008. doi: 10.1590/ S1984-29612008000400008.

PINTER, A. Febre maculosa brasileira - vigilância acarológica e controle. In: MEIRA, A. M.; COOPER, M.; FERRAZ, K. M. P. M. B.; MONTI, J. A.; CARAMEZ, R. B.; DELITTI, W. B. C. (Org.). Febre maculosa: dinâmica da doença, hospedeiros e vetores. Piracicaba: ESALQ, 2013. 176 p.

PINTER, A.; FRANÇA, A. C.; SOUZA, C. E.; SABBO, C.; NASCIMENTO, E. M. M.; SANTOS, F. C. P.; LABRUNA, M. B.; HOLCMAN, M. M.; ALVES, M. J. C. P.; HORTA, M. C.; MASCHERETTI, M.; MAYO, R.C.; ANGERAMI, R. N.; BRASIL, R. A.; SOUZA, S. S. A. L.; COLOMBO, S.; OLIVEIRA, V. L. M. Febre maculosa brasileira. Boletim Epidemiológico Paulista, v. 8, n. 1, p. 1-31, 2011. Available from: <http://www.saude.sp.gov.br/resources/ sucen/homepage/downloads/arquivos-de-febre-maculosa/ bepa94_suplemento_fmb.pdf >. Viewed: Dec. 14th, 2018.

PIZA, J. T. Considerações epidemiológicas e clínicas sobre o tifo exantemático de São Paulo. In: PIZA, J. T.; MEYER, J. R.; SALLES-GOMES, L. (Ed.). Tifo exantemático de
São Paulo. São Paulo: Sociedade Impressora Paulista, 1932. p. 11-119.

PRATT, J. W. Remarks on zeros and ties in the Wilcoxon signed rank procedures. Journal of the American Statistical Association, v. 54, n. 287, p. 655-667, 1959. doi: $10.2307 / 2282543$.

R CORE TEAM. R: a language and environment for statistical computing. Vienna: R Foundation for Statistical Computing, 2013. Available from: <https://www.R-project. org/>. Viewed: June 16th, 2018.

RIBEIRO, M. D.; FURTADO, M. A.; FERRAUDO, A. S.; CESARIO, M.; MORRAYE, M. A. Fatores ambientais envolvidos na epidemiologia da febre maculosa no estado de São Paulo. Hygeia, v. 9, n. 16, p. 103-114, 2013. Available from: <http://www.seer.ufu.br/index.php/hygeia/article/ view/20927/12456>. Viewed: Dec. 14th, 2018.

ROHR, C. Estudo sobre ixódidas do Brasil. Rio de Janeiro: Instituto Oswaldo Cruz, 1909. 220 p.

SANGIONI, L. A.; HORTA, M. C.; VIANNA, M. C. B.; GENNARI, S. M.; SOARES, R. M.; GALVÃO, M. A. M.; SCHUMAKER, T. T. S.; FERREIRA, F.; VIDOTTO, O.; LABRUNA, M. B. Rickettsial infection in animals and Brazilian spotted fever endemicity. Emerging Infectious Diseases, v. 11, n. 2, p. 265-270, 2005. doi: 10.3201/ eid1102.040656.

SÃO PAULO (Estado). Secretaria de Estado da Saúde Superintendência de Controle de Endemias. Manual de vigilância acarológica do estado de São Paulo. São Paulo: SUCEN, 2004. 60 p.

SCHALLER, G. B.; CRAWSHAW JUNIOR, P. G. Social organization in a capybara population. Säugetierkundlichen Mitteilungen, v. 29, n. 1, p. 3-16, 1981.

SERRA-FREIRE, N. M. Ixodídeos parasitas de bovinos leiteiros na zona fisiográfica de Resende, estado do Rio de Janeiro. Revista Brasileira de Medicina Veterinária, v. 5, n. 3, p. 18-20, 1982.

SOUZA, A. P. Variação populacional dos principais ixodídeos parasitas de bovinos e eqüinos em diferentes 
condições de manejo nos municípios de Paracambi e Itaguaí no estado do Rio de Janeiro. 1990. 81 f. Tese (Doutorado em Ciências Veterinárias) - Instituto de Veterinária, Universidade Federal Rural do Rio de Janeiro, Seropédica, 1990.

SOUZA, C. E.; MORAES-FILHO, J.; OGRZEWALSKA, M.; UCHOA, F. C.; HORTA, M. C.; SOUZA, S. S. L.; BORBA, M.; LABRUNA, M. B. Experimental infection of capybaras Hydrochoerus hydrochaeris by Rickettsia rickettsii and evaluation of the transmission of the infection to ticks Amblyomma cajennense. Veterinary Parasitology, v. 161, n. 1-2, p. 116-121, 2009. doi: 10.1016/j. vetpar.2008.12.010.

SOUZA, C. E.; PINTER, A.; DONALISIO, M. R. Risk factors associated with the transmission of Brazilian spotted fever in the Piracicaba river basin, State of São Paulo, Brazil. Revista da Sociedade Brasileira de Medicina Tropical, v. 48, n. 1, p. 11-17, 2015. doi: 10.1590/0037-8682-0281-2014.

SOUZA, C. E.; SOUZA, S. S. L.; LIMA, V. L. C.; CALIC, S. B.; CAMARGO, M. C. G. O.; SAVANI, E. S. M. M.; D’AURIA, S. R. N.; LINHARES, A. X.; YOSHINARI, N. H. Serological identification of Rickettsia spp from the spotted fever group in capybaras in the region of
Campinas - SP - Brazil. Ciência Rural, v. 38, n. 6, p. 16941699, 2008. doi: 10.1590/S0103-84782008000600031.

SPIESS, A.-N. QpcR: modelling and analysis of real-time PCR data. R package version 1.4-0. Vienna: CRAN, 2014. Available from: <https:/cran.r-project.org/web/packages/ qpcR/index.html>. Viewed: June 16th, 2018.

UENO, T. E. H.; COSTA, F. B.; MORAES-FILHO, J.; AGOSTINHO, W. C.; FERNANDES, W. R.; LABRUNA, M. B. Experimental infection of horses with Rickettsia rickettsii. Parasites \& Vectors, v. 9, n. 499, p. 1-11. doi: 10.1186/s13071-016-1784-y.

WAGENMAKERS, E.-J.; FARRELL, S. AIC model selection using Akaike weights. Psychonomic Bulletin \& Review, v. 11, n. 1, p. 192-196, 2004. doi: 10.3758/BF03206482.

ZEILEIS, A.; GROTHENDIECK, G. Zoo: S3 infrastructure for regular and irregular time series. Journal of Statistical Software, v. 14, n. 6, p. 1-27, 2005. doi: 10.18637/jss.v014.i06.

ZEILEIS, A.; HOTHORN, T. Diagnostic checking in regression relationships. R News, v. 2, n. 3, p. 7-10, 2002. Available from: <https://cran.r-project.org/web/packages/lmtest/vignettes/ lmtest-intro.pdf>. Viewed: Dec. 16th, 2018. 